\title{
LEVEL II SCOUR ANALYSIS FOR BRIDGE 65 (NEWBTH00500065) on TOWN HIGHWAY 50, crossing PEACH BROOK, NEWBURY, VERMONT
}

Open-File Report 97-804

Prepared in cooperation with

VERMONT AGENCY OF TRANSPORTATION

and

FEDERAL HIGHWAY ADMINISTRATION

U.S. Department of the Interior U.S. Geological Survey

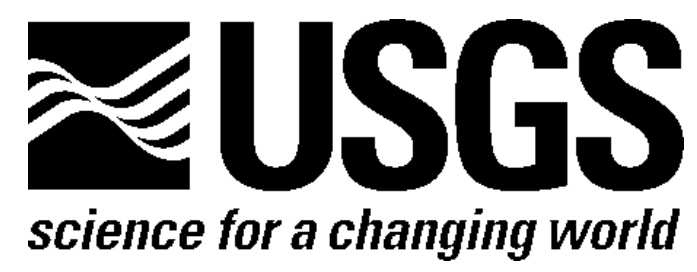




\section{LEVEL II SCOUR ANALYSIS FOR BRIDGE 65 (NEWBTH00500065) on TOWN HIGHWAY 50, crossing PEACH BROOK, NEWBURY, VERMONT \\ By RONDA L. BURNS and TIM SEVERANCE}

U.S. Geological Survey Open-File Report 97-804

Prepared in cooperation with

VERMONT AGENCY OF TRANSPORTATION

and

FEDERAL HIGHWAY ADMINISTRATION 


\title{
U.S. DEPARTMENT OF THE INTERIOR BRUCE BABBITT, Secretary
}

\author{
U.S. GEOLOGICAL SURVEY \\ Mark Schaefer, Acting Director
}

For additional information write to:

District Chief

U.S. Geological Survey 361 Commerce Way

Pembroke, NH 03275-3718
Copies of this report may be purchased from:

U.S. Geological Survey

Branch of Information Services

Open-File Reports Unit

Box 25286

Denver, CO 80225-0286 


\section{CONTENTS}

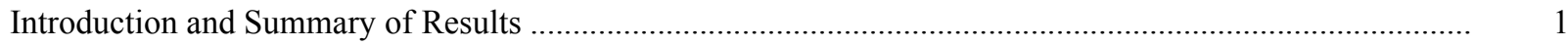

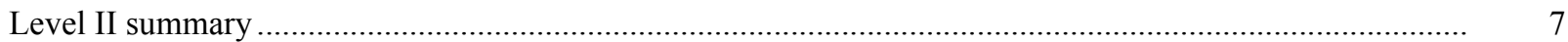

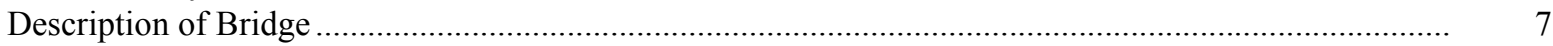

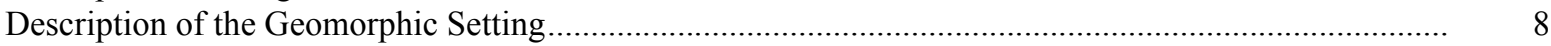

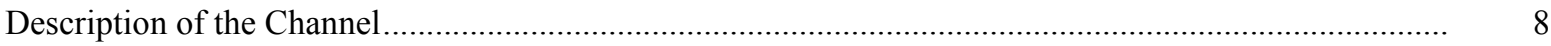

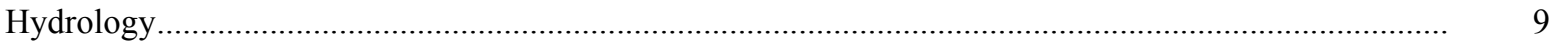

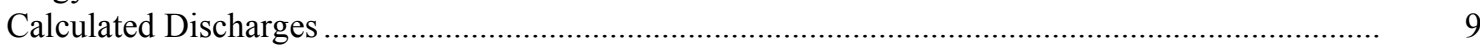

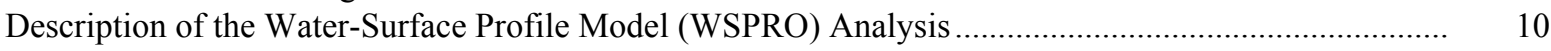

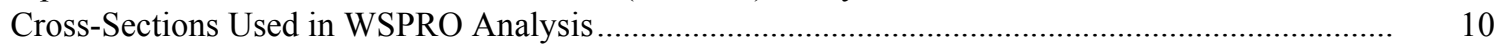

Data and Assumptions Used in WSPRO Model ...................................................................... 11

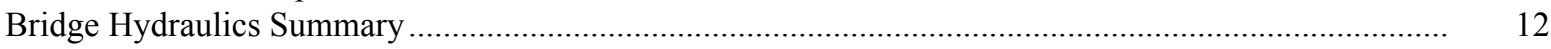

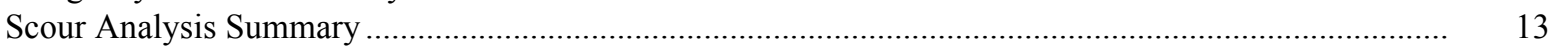

Special Conditions or Assumptions Made in Scour Analysis ...................................................... 13

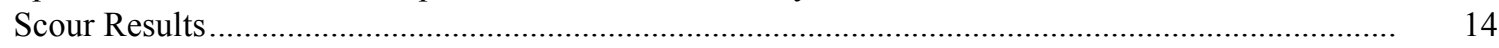

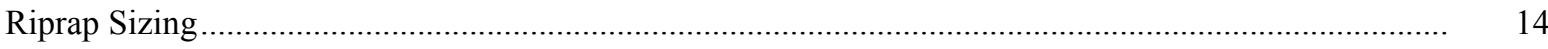

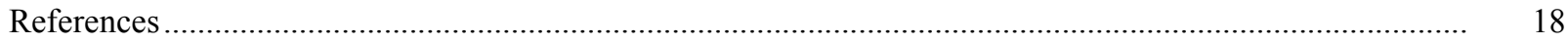

Appendixes:

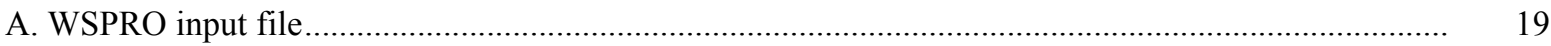

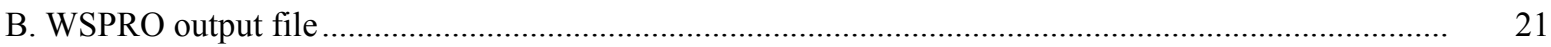

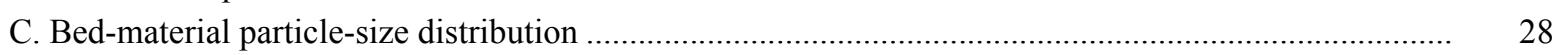

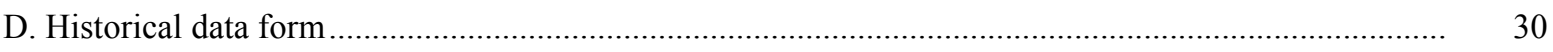

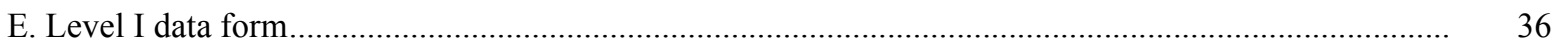

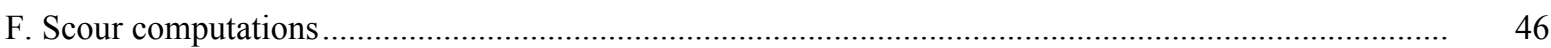

\section{FIGURES}

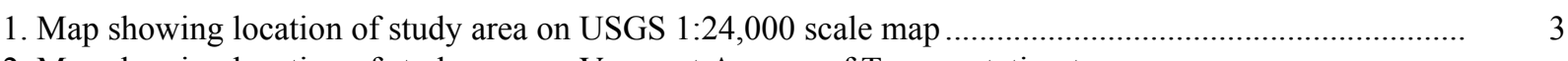

2. Map showing location of study area on Vermont Agency of Transportation town
highway map

3. Structure NEWBTH00500065 viewed from upstream (August 29, 1995) ............................................. 5

4. Downstream channel viewed from structure NEWBTH00500065 (August 29, 1995)........................... 5

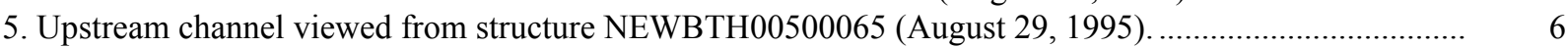

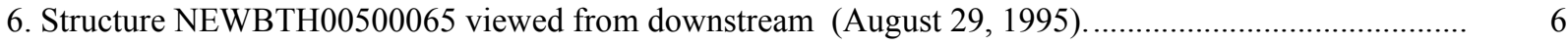

7. Water-surface profiles for the 100- and 500-year discharges at structure

NEWBTH00500065 on Town Highway 50, crossing Peach Brook,

Newbury, Vermont.

8. Scour elevations for the 100- and 500-year discharges at structure

NEWBTH00500065 on Town Highway 50, crossing Peach Brook,

Newbury, Vermont.

\section{TABLES}

1. Remaining footing/pile depth at abutments for the 100-year discharge at structure

NEWBTH00500065 on Town Highway 50, crossing Peach Brook,

Newbury, Vermont.

2. Remaining footing/pile depth at abutments for the 500-year discharge at structure

NEWBTH00500065 on Town Highway 50, crossing Peach Brook,

Newbury, Vermont. 


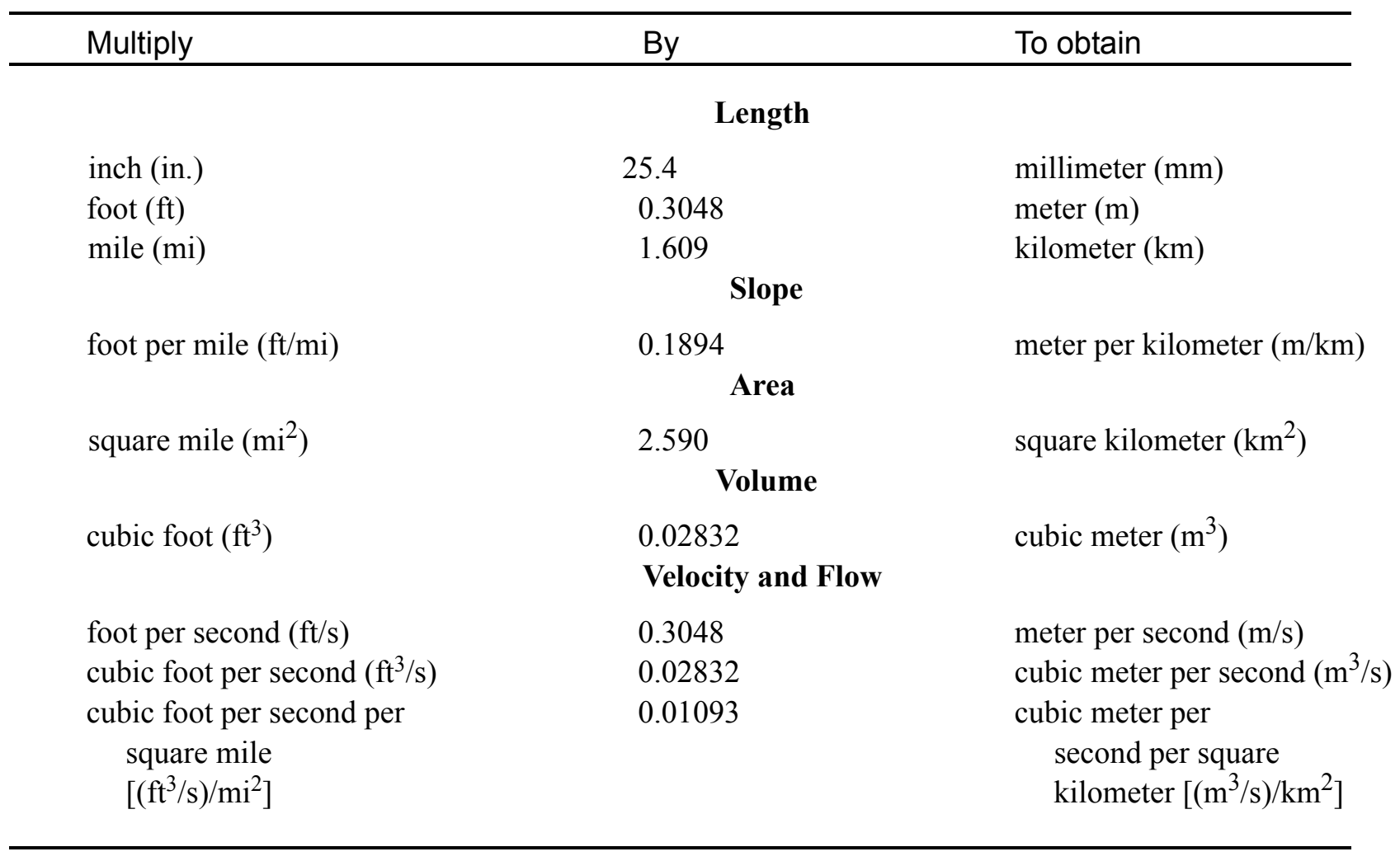

\section{OTHER ABBREVIATIONS}

$\begin{array}{lrlr}\mathrm{BF} & \text { bank full } & \text { LWW } & \text { left wingwall } \\ \mathrm{cfs} & \text { cubic feet per second } & \text { MC } & \text { main channel } \\ \mathrm{D}_{50} & \text { median diameter of bed material } & \text { RAB } & \text { right abutment } \\ \mathrm{DS} & \text { downstream } & \text { RABUT } & \text { face of right abutment } \\ \mathrm{elev} & \text { elevation } & \text { RB } & \text { right bank } \\ \mathrm{f} / \mathrm{p} & \text { flood plain } & \text { ROB } & \text { right overbank } \\ \mathrm{ft}^{2} & \text { square feet } & \text { RWW } & \text { right wingwall } \\ \mathrm{ft} / \mathrm{ft} & \text { feet per foot } & \text { TH } & \text { town highway } \\ \mathrm{JCT} & \text { junction } & \text { UB } & \text { under bridge } \\ \mathrm{LAB} & \text { left abutment } & \text { US } & \text { upstream } \\ \mathrm{LABUT} & \text { face of left abutment } & \text { USGS } & \text { United States Geological Survey } \\ \mathrm{LB} & \text { left bank } & \text { VTAOT Vermont Agency of Transportation } \\ \mathrm{LOB} & \text { left overbank } & \text { WSPRO } & \text { water-surface profile model }\end{array}$

In this report, the words "right" and "left" refer to directions that would be reported by an observer facing downstream. Sea level: In this report, "sea level" refers to the National Geodetic Vertical Datum of 1929-- a geodetic datum derived from a general adjustment of the first-order level nets of the United States and Canada, formerly called Sea Level Datum of 1929.

In the appendices, the above abbreviations may be combined. For example, USLB would represent upstream left bank. 


\title{
LEVEL II SCOUR ANALYSIS FOR BRIDGE 65 (NEWBTH00500065) ON TOWN HIGHWAY 50, CROSSING PEACH BROOK, NEWBURY, VERMONT
}

\author{
By Ronda L. Burns and Tim Severance
}

\section{INTRODUCTION AND SUMMARY OF RESULTS}

This report provides the results of a detailed Level II analysis of scour potential at structure NEWBTH00500065 on Town Highway 50 crossing Peach Brook, Newbury, Vermont (figures 1-8). A Level II study is a basic engineering analysis of the site, including a quantitative analysis of stream stability and scour (U.S. Department of Transportation, 1993). Results of a Level I scour investigation also are included in Appendix E of this report. A Level I investigation provides a qualitative geomorphic characterization of the study site. Information on the bridge, gleaned from Vermont Agency of Transportation (VTAOT) files, was compiled prior to conducting Level I and Level II analyses and is found in Appendix D.

The site is in the New England Upland section of the New England physiographic province in east-central Vermont. The $15.3-\mathrm{mi}^{2}$ drainage area is in a predominantly rural and forested basin. In the vicinity of the study site, the surface cover is forest upstream of the bridge and shrub and brushland downstream of the bridge.

In the study area, Peach Brook has an incised, sinuous channel with a slope of approximately $0.005 \mathrm{ft} / \mathrm{ft}$, an average channel top width of $40 \mathrm{ft}$ and an average bank height of $8 \mathrm{ft}$. The channel bed material ranges from cobble to boulder with a median grain size $\left(\mathrm{D}_{50}\right)$ of $83.1 \mathrm{~mm}(0.273 \mathrm{ft})$. The geomorphic assessment at the time of the Level I and Level II site visit on August 29, 1995, indicated that the reach was stable.

The Town Highway 50 crossing of the Peach Brook is a 29-ft-long, two-lane bridge consisting of one 25-foot steel-beam span (Vermont Agency of Transportation, written communication, March 27, 1995). The opening length of the structure parallel to the bridge face is $24.9 \mathrm{ft}$. The bridge is supported by vertical, concrete abutments with wingwalls. The channel is skewed approximately 50 degrees to the opening while the computed openingskew-to-roadway is 20 degrees. 
A channel scour hole $0.75 \mathrm{ft}$ deeper than the mean thalweg depth was observed under the bridge during the Level I assessment. Also observed was channel scour $0.75 \mathrm{ft}$ deeper than the mean thalweg at the upstream face of the bridge and channel scour $0.25 \mathrm{ft}$ deeper than the mean thalweg along the right bank downstream. The scour protection measures at the site included type- 1 stone fill (less than 12 inches diameter) along the upstream and downstream right wingwalls and type- 2 stone fill (less than 36 inches diameter) along the upstream right bank and along the downstream left wingwall and bank. In addition, there are four $3 \mathrm{ft}$ square concrete blocks at the corner where the upstream right wingwall joins the right abutment. The upstream left wingwall and upstream half of the left abutment were constructed on top of a bedrock outcrop. Additional details describing conditions at the site are included in the Level II Summary and Appendices D and E.

Scour depths and recommended rock rip-rap sizes were computed using the general guidelines described in Hydraulic Engineering Circular 18 (Richardson and others, 1995) for the 100- and 500-year discharges. In addition, the incipient roadway-overtopping discharge is determined and analyzed as another potential worst-case scour scenario. Total scour at a highway crossing is comprised of three components: 1) long-term streambed degradation; 2) contraction scour (due to accelerated flow caused by a reduction in flow area at a bridge) and; 3) local scour (caused by accelerated flow around piers and abutments). Total scour is the sum of the three components. Equations are available to compute depths for contraction and local scour and a summary of the results of these computations follows.

Contraction scour for all modelled flows ranged from 0.0 to $1.3 \mathrm{ft}$. The worst-case contraction scour occurred at the incipient roadway-overtopping discharge, which was less than the 100-year discharge. The right abutment scour ranged from 6.1 to $7.2 \mathrm{ft}$. The worstcase right abutment scour occurred at the incipient roadway-overtopping discharge. The left abutment scour ranged from 7.1 to $10.3 \mathrm{ft}$. The worst-case left abutment scour occurred at the 500-year discharge. Additional information on scour depths and depths to armoring are included in the section titled "Scour Results". Scoured-streambed elevations, based on the calculated scour depths, are presented in tables 1 and 2. A cross-section of the scour computed at the bridge is presented in figure 8. Scour depths were calculated assuming an infinite depth of erosive material and a homogeneous particle-size distribution.

It is generally accepted that the Froehlich equation (abutment scour) gives "excessively conservative estimates of scour depths" (Richardson and others, 1995, p. 47). Usually, computed scour depths are evaluated in combination with other information including (but not limited to) historical performance during flood events, the geomorphic stability assessment, existing scour protection measures, and the results of the hydraulic analyses. Therefore, scour depths adopted by VTAOT may differ from the computed values documented herein. 


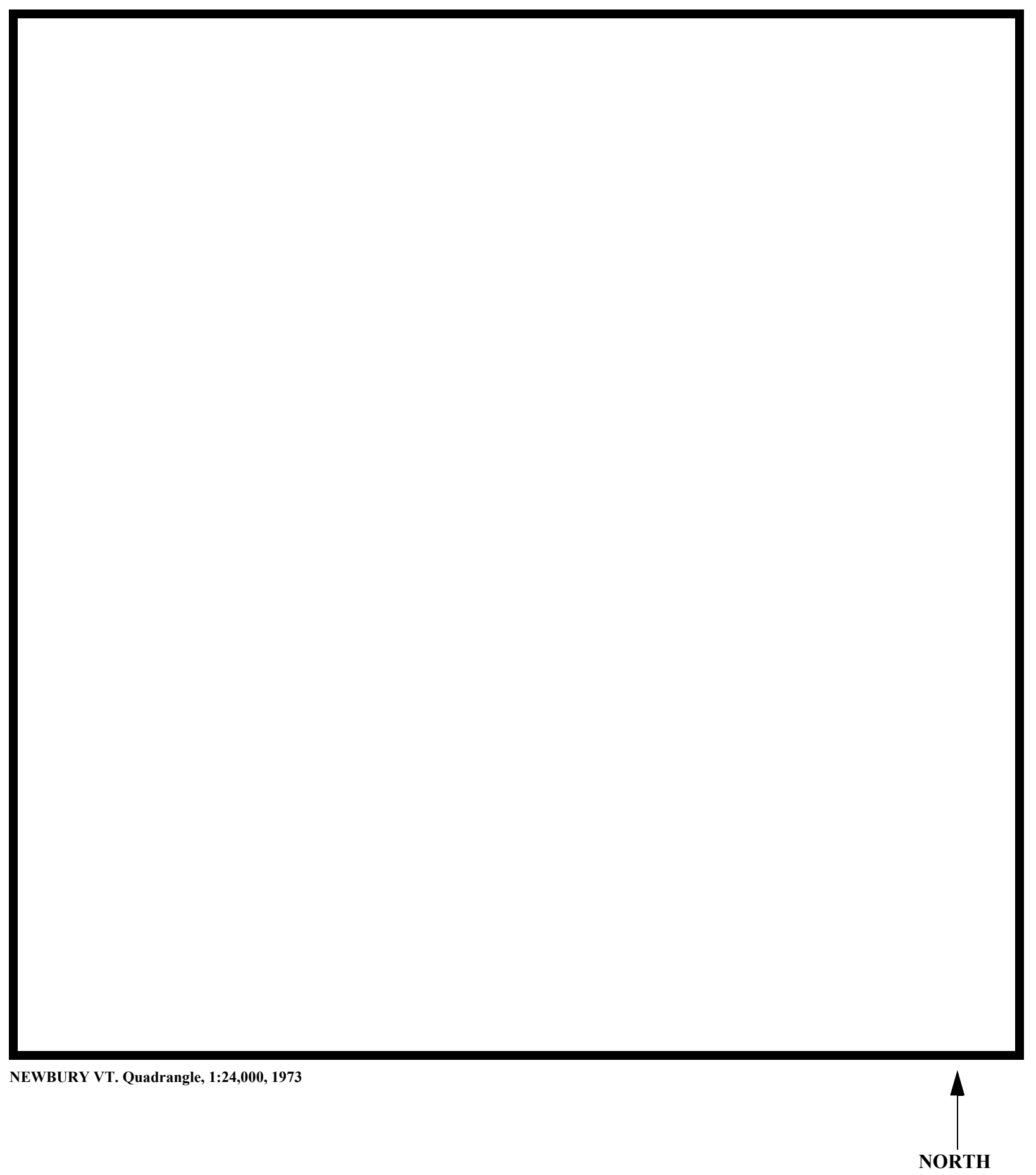

Figure 1. Location of study area on USGS 1:24,000 scale map. 
Figure 2. Location of study area on Vermont Agency of Transportation town highway map. 

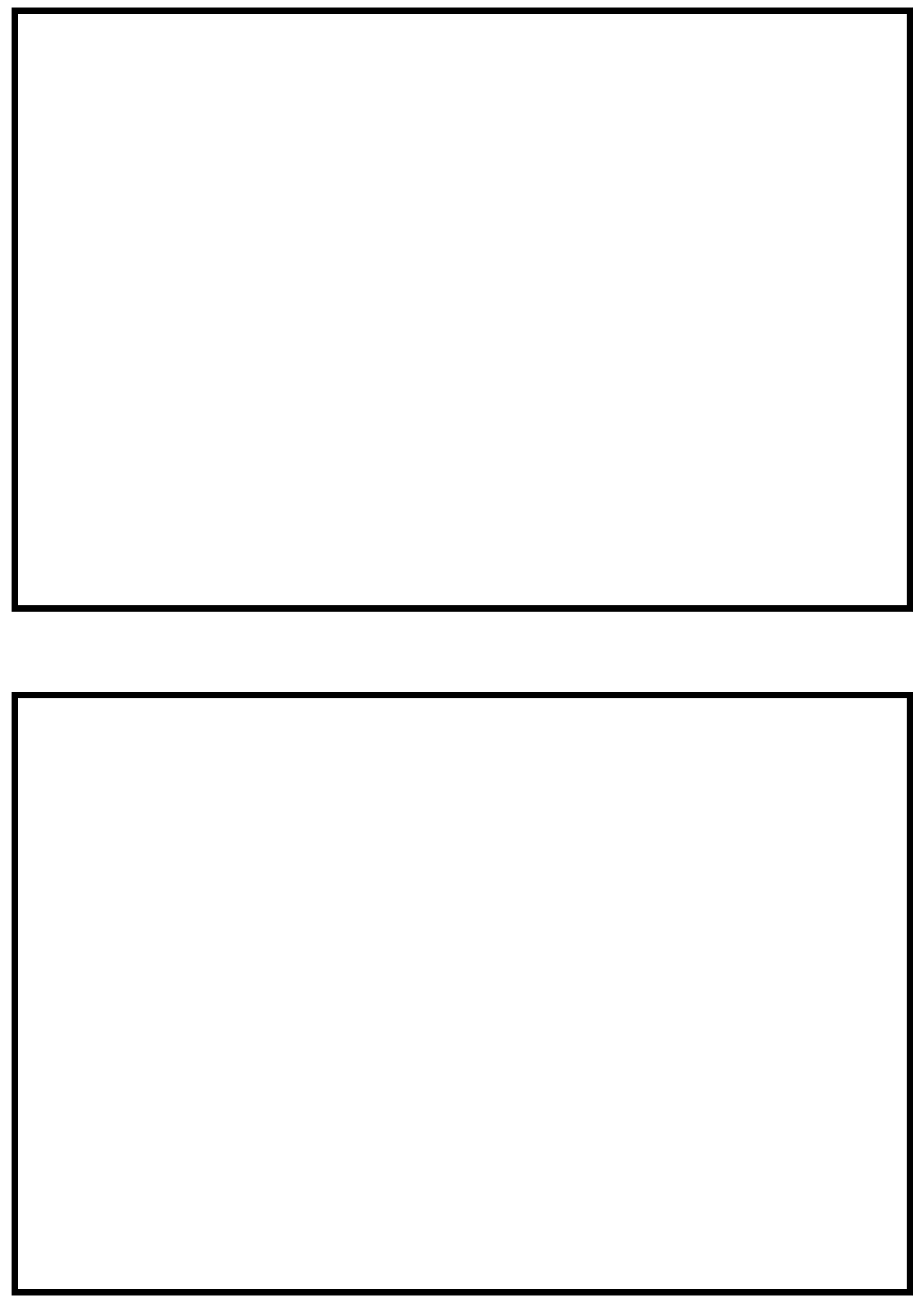

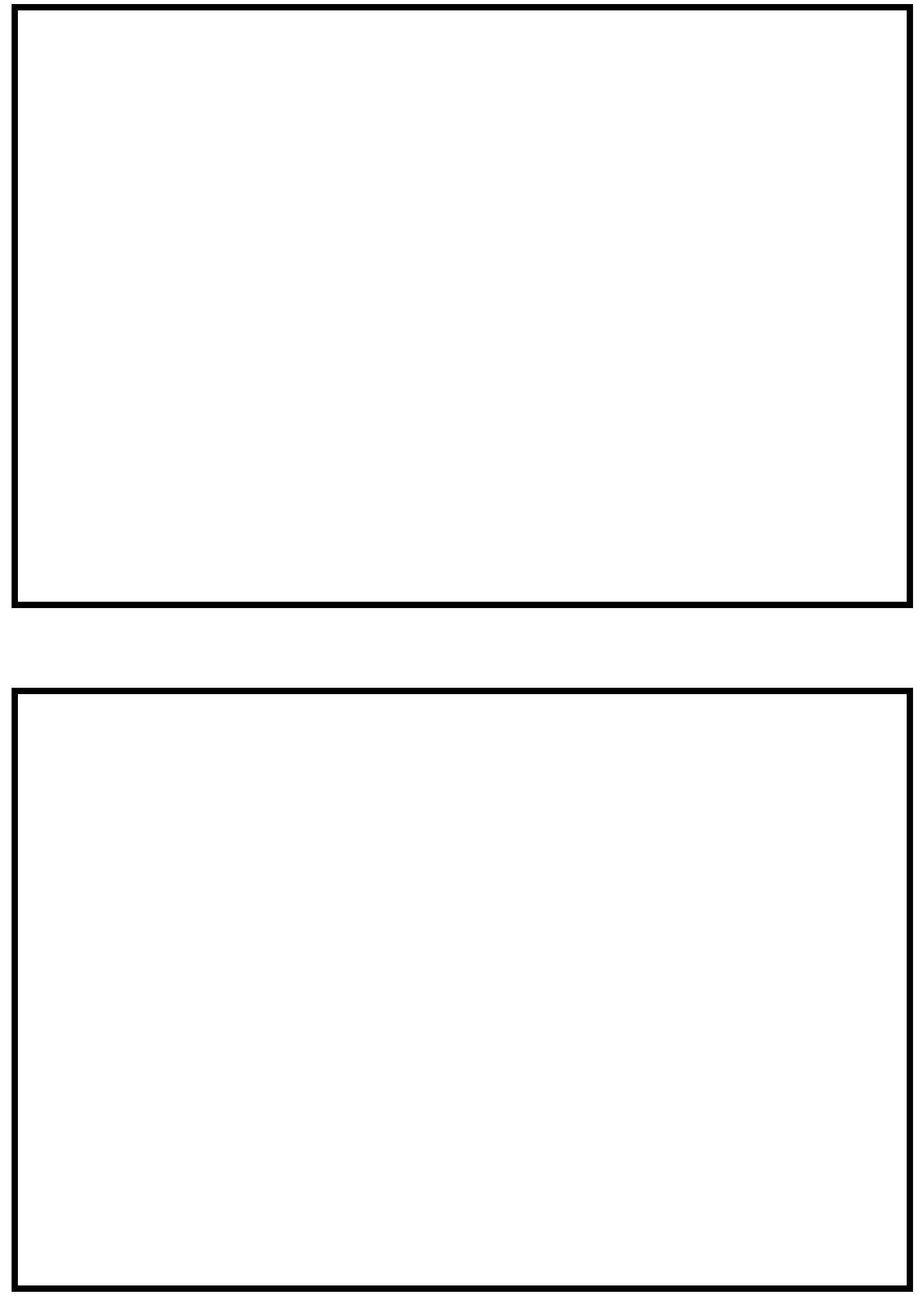


\section{LEVEL II SUMMARY}

\begin{tabular}{llllll} 
Structure Number & NEWBTH00500065 & Stream & \multicolumn{2}{c}{ Peach Brook } \\
& Road & TH 50 & District & Roung
\end{tabular}

\section{Description of Bridge}

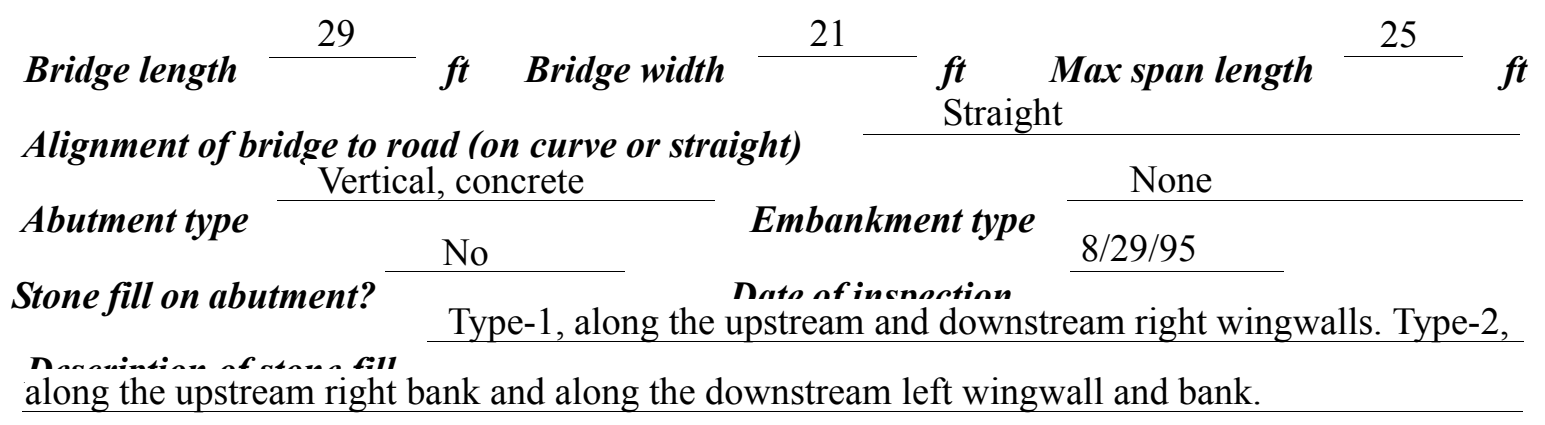

Abutments and wingwalls are concrete. The upstream half of the left abutment and upstream left wingwall are on bedrock. There is a 0.75 foot deep

channel scour hole under the bridge.

Yes

$50 \quad$ Yes

Is bridge skewed to flood flow according to There 'survey? Angle

is a mild channel bend in the upstream reach. The bank material is eroded and bedrock is exposed where the stream impacts the upstream left bank.

Debris accumulation on bridge at time of Level I or Level II site visit:

Date of insnortion $8 / 29 / 95$

Level I

$8 / 29 / 95$

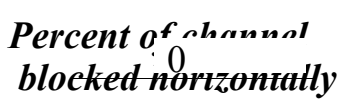

blocked inortzontatly

0
Percent of anchel
blocked verticatty

0

Level II

Moderate. The banks are well vegetated and some trees are leaning over the channel upstream.

Potential for debris

A bedrock outcrop is exposed along the upstream left bank and under the upstream half of the Doscriho anv, fonturos noar ar at tho hridoo that mav, affort flow, (includo ahsorvation dato). left abutment as of $8 / 29 / 95$. Channel scour has developed where the stream impacts the bedrock at

the upstream bridge face and under the bridge. 


\section{Description of the Geomorphic Setting}

General topography The channel is located within a moderate relief valley with a narrow flood plain.

Geomorphic conditions at bridge site: downstream (DS), upstream (US)

Date of inspection $\quad 8 / 29 / 95$

DS left: $\quad$ Steep channel bank

DS right: $\quad$ Narrow flood plain

US left: $\quad$ Steep valley wall

US right: $\quad$ Steep channel bank to a narrow flood plain

\section{Description of the Channel}

\begin{tabular}{|c|c|c|c|}
\hline & 0 & & 8 \\
\hline Average top width & Cobbles/Boulders & Average depth & Cobbles/Boulders \\
\hline
\end{tabular}

Predominant bed material

Bank material Sinuous but stable

with non-alluvial channel boundaries and a narrow flood plain."

$8 / 29 / 95$

Vegetative co 1 Brush and trees

DS left: $\quad$ Brush and trees

DS right: Trees

US left: $\quad$ Trees

US right: $\quad$ Yes

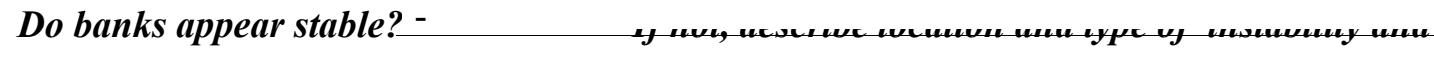

date oj observation.

There are four $3 \mathrm{ft}$

square concrete blocks at the upstream end of the right abutment and along the upstream right Describe any obstructions in channel and date of observation. wingwall as of $8 / 29 / 95$. 


\title{
Hydrology
}

Drainage area $\frac{15.3}{\boldsymbol{m i}^{2}}$

Percentage of drainage area in physiographic provinces: (approximate)

Physiographic province/section New England/New England Upland
Percent of drainage area 100

\begin{abstract}
Is drainage area considered rural or urban?
Rural None.

urbanization:-

Describe any significant
\end{abstract}

Is there a USGS gage on the stream of interest?

No

USGS gage description

USGS gage number

Gage drainage area $\mathrm{mi}^{2}$

$--$

USGS gage number
Gage drainage area

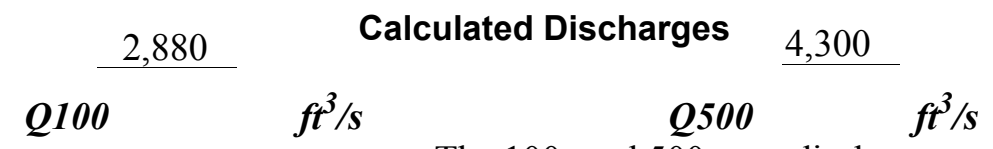

The 100- and 500-year discharges are based on a

drainage area relationship [(15.3/15.8)exp 0.67] with bridge number 6 in Newbury. Bridge number 6 crosses Peach Brook downstream of this site and has flood frequency estimates available from the VTAOT database. The drainage area above bridge number 6 is 15.8 square miles. The values used were within a range defined by flood frequency curves developed from several empirical methods (Benson, 1962; Johnson and Tasker, 1974; FHWA, 1983; Potter, 1957a\&b; Talbot, 1887). 


\section{Description of the Water-Surface Profile Model (WSPRO) Analysis}

Datum for WSPRO analysis (USGS survey, sea level, VTAOT plans)

USGS survey

Datum tie between USGS survey and VTAOT plans

None

Description of reference marks used to determine USGS datum. $\quad$ RM1 is a chiseled X on

top of the downstream end of the right abutment (elev. $499.15 \mathrm{ft}$, arbitrary survey datum). RM2

is a chiseled $\mathrm{X}$ on top of the upstream end of the right abutment (elev. $498.93 \mathrm{ft}$, arbitrary survey

datum). RM3 is a chiseled square in the bedrock on the upstream left bank (elev. $491.48 \mathrm{ft}$,

arbitrary survey datum).

\section{Cross-Sections Used in WSPRO Analysis}

\begin{tabular}{|c|c|c|c|}
\hline${ }^{1}$ Cross-section & $\begin{array}{c}\text { Section } \\
\text { Reference } \\
\text { Distance } \\
\text { (SRD) in feet }\end{array}$ & $\begin{array}{c}{ }^{2} \text { Cross-section } \\
\text { development }\end{array}$ & Comments \\
\hline EXIT2 & -20 & 1 & Exit section \\
\hline FULLV & 0 & 2 & $\begin{array}{l}\text { Downstream Full-valley } \\
\text { section (Templated from } \\
\text { EXIT2) }\end{array}$ \\
\hline BRIDG & 0 & 1 & Bridge section \\
\hline RDWAY & 13 & 1 & Road Grade section \\
\hline APPR2 & 50 & 1 & Approach section \\
\hline
\end{tabular}

${ }^{1}$ For location of cross-sections see plan-view sketch included with Level I field form, Appendix E. For more detail on how cross-sections were developed see WSPRO input file. 


\section{Data and Assumptions Used in WSPRO Model}

Hydraulic analyses of the reach were done by use of the Federal Highway Administration's WSPRO step-backwater computer program (Sherman and others, 1986, and Sherman, 1990). The analyses reported herein reflect conditions existing at the site at the time of the study. Furthermore, in the development of the model it was necessary to assume no accumulation of debris or ice at the site. Results of the hydraulic model are presented in the Bridge Hydraulic Summary, Appendix B, and figure 7.

Channel roughness factors (Manning's “ $n$ ”) used in the hydraulic model were estimated using field inspections at each cross section following the general guidelines described by Arcement and Schneider (1989). Final adjustments to the values were made during the modelling of the reach. Channel " $n$ " values for the reach ranged from 0.045 to 0.050 , and overbank " $n$ " values ranged from 0.070 to 0.075 .

Normal depth at the exit section (EXIT2) was assumed as the starting water surface. This depth was computed by use of the slope-conveyance method outlined in the user's manual for WSPRO (Sherman, 1990). The slope used was $0.0054 \mathrm{ft} / \mathrm{ft}$ which was estimated from the topographic map (U.S. Geological Survey, 1973).

The modeled approach section (APPR2) was surveyed one bridge length upstream of the upstream face as recommended by Sherman and others (1986). This location provides a consistent method for determining scour variables.

For the incipient-overtopping discharge, WSPRO assumes critical depth at the bridge section. A supercritical model was developed for this discharge. After analyzing both the supercritical and subcritical profiles for this discharge, it was determined that the water surface profile does pass through critical depth within the bridge opening. Thus, the assumption of critical depth at the bridge is a satisfactory solution. 


\section{Bridge Hydraulics Summary}

$\begin{array}{llll}\text { Average bridge embankment elevation } & 500.2 & f t \\ \text { Average low steel elevation } & 497.7 & \boldsymbol{f t}\end{array}$

100-year discharge $\quad 2,880 \quad \mathrm{ft}^{3} / \mathrm{s}$

Water-surface elevation in bridge opening $\quad 497.7 \quad f t$

Road overtopping? ___ Yes Discharge over road _ $1,137,3 / \mathbf{s}$

\begin{tabular}{lll} 
Area of flow in bridge opening & $204 \quad \mathrm{ft}^{2}$ \\
\cline { 2 - 3 } Average velocity in bridge opening & 8.5 & $\mathrm{ft} / \mathrm{s}$
\end{tabular}

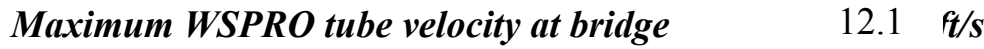

Water-surface elevation at Approach section with bridge 499.1

Water-surface elevation at Approach section without bridge $\quad 496.5$

Amount of backwater caused by bridge

$2.6 i$

500-year discharge $\quad 4,300 \quad \boldsymbol{f t}^{3} / \mathrm{s}$

Water-surface elevation in bridge opening

$497.7 f t$

Road overtopping? ___ Yes Discharge over road _ 2,358 _'s

Area of flow in bridge opening $\quad 204 \quad \mathrm{ft}^{2}$

Average velocity in bridge opening $\quad 9.7 \mathrm{ft} / \mathrm{s}$

Maximum WSPRO tube velocity at bridge 13.9 /s

Water-surface elevation at Approach section with bridge 499.9

Water-surface elevation at Approach section without bridge $\quad 499.6$

Amount of backwater caused by bridge 0.3 , $t$

Incipient overtopping discharge $\quad 1,780 \mathrm{ft}^{3} / \mathrm{s}$

Water-surface elevation in bridge opening 494.6 t

Area of flow in bridge opening $131 \quad \mathrm{ft}^{2}$

Average velocity in bridge opening $\quad 13.5 \quad \mathrm{ft} / \mathrm{s}$

Maximum WSPRO tube velocity at bridge $\quad 18.7 \quad \mathrm{ft} / \mathrm{s}$

Water-surface elevation at Approach section with bridge

Water-surface elevation at Approach section without bridge

498.0

Amount of backwater caused by bridge $\quad 3.8$.t 


\section{Scour Analysis Summary}

\section{Special Conditions or Assumptions Made in Scour Analysis}

Scour depths were computed using the general guidelines described in Hydraulic Engineering Circular 18 (Richardson and others, 1995). Scour depths were calculated assuming an infinite depth of erosive material and a homogeneous particle-size distribution. However, there is bedrock in the channel along the upstream left bank and under the upstream half of the left abutment. The results of the scour analysis for the 100- and 500-year discharges are presented in Tables 1 and 2 and a graph of the scour depths is presented in Figure 8.

Contraction scour for the incipient roadway-overtopping discharge was computed by use of the Laursen clear-water contraction scour equation (Richardson and others, 1995, p. 32, equation 20). At this site, the 100-year and 500-year discharges resulted in unsubmerged orifice flow. Contraction scour at bridges with orifice flow is best estimated by use of the Chang pressure-flow scour equation (oral communication, J. Sterling Jones, October 4, 1996). Thus, contraction scour for these discharges was computed by use of the Chang equation (Richardson and others, 1995, p. 145-146). Results of this scour analysis are shown in Tables 1 and 2 and Figure 8. The streambed armoring depths computed suggest that armoring will not limit the depth of contraction scour.

For comparison, estimates of contraction scour for the 100-year and 500-year discharges also were computed by use of the Laursen clear-water contraction scour equation and the Umbrell pressure-flow equation (Richardson and others, 1995, p. 144) and are presented in Appendix F. At the 500-year discharge the average channel velocity and the incipient-motion velocity of the bed material are nearly the same, therefore, estimates of contraction scour at this discharge were also computed by use of the Laursen live-bed contraction scour equation (Richardson and others, 1995, p.30, equation 17). Furthermore, for those discharges resulting in unsubmerged orifice flow, contraction scour was computed by substituting estimates for the depth of flow at the downstream bridge face in the contraction scour equations. Results with respect to these substitutions are provided in Appendix F.

Abutment scour was computed by use of the Froehlich equation (Richardson and others, 1995, p. 48, equation 28). Variables for the Froehlich equation include the Froude number of the flow approaching the embankments, the length of the embankment blocking flow, and the depth of flow approaching the embankment less any roadway overtopping. 


\section{Scour Results}

\section{0-yr discharge 500-yr discharge}

Contraction scour:

(Scour depths in feet)

Main channel

Live-bed scour

Clear-water scour

Depth to armoring

Left overbank

Right overbank

Local scour:

Abutment scour

Left abutment

8.7

10.3

7.1

$6.1-$

$7.0-$

$7.2-$

Right abutment

Pier scour

Pier 1

Pier 2

Pier 3

\section{Abutments:}

Left abutment

Right abutment

Piers:

Pier 1

Pier 2

overtopping discharge 


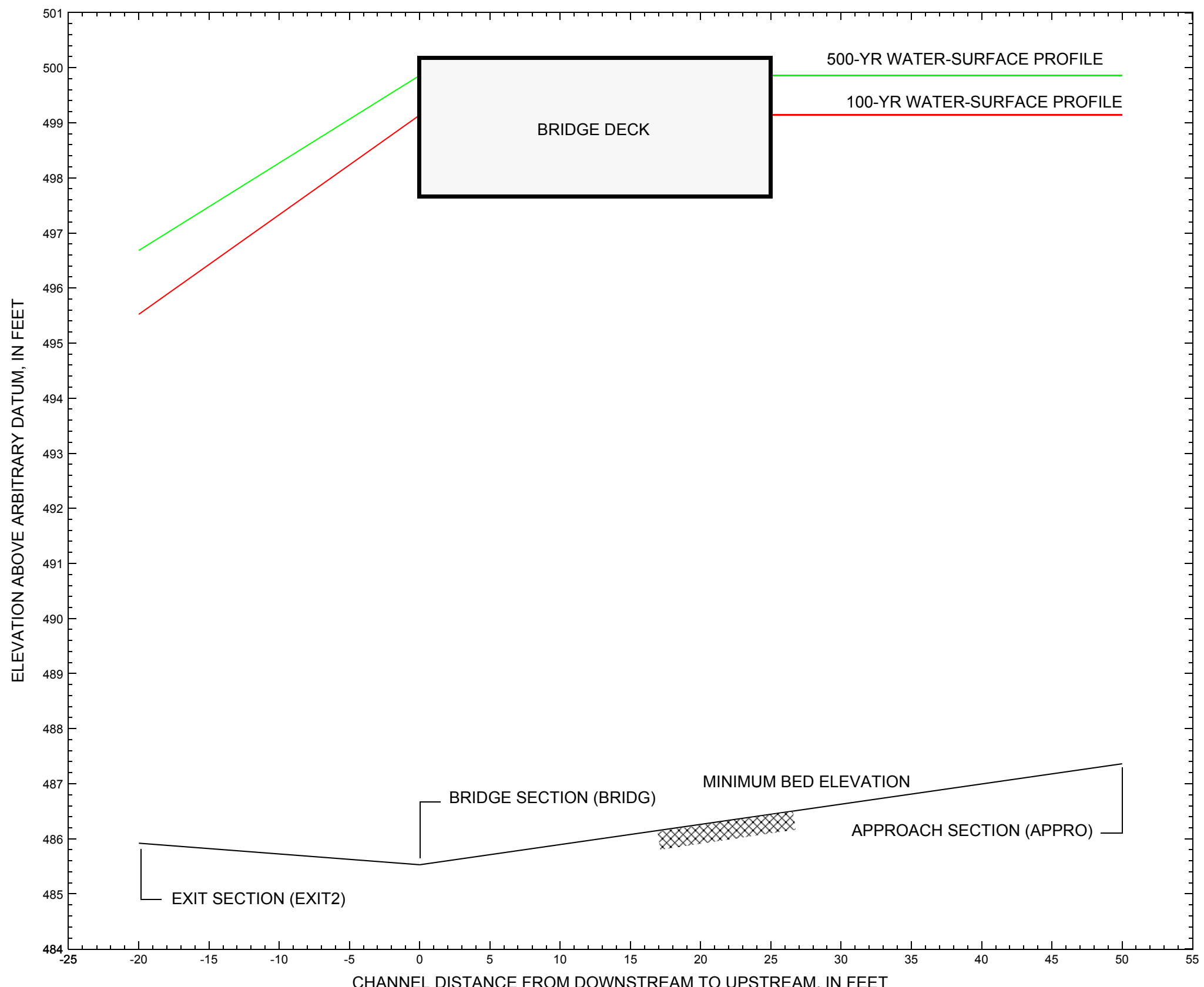

Figure 7. Water-surface profiles for the 100- and 500-yr discharges at structure NEWBTH00500065 on Town Highway 50, crossing Peach Brook, Newbury, Vermont. 


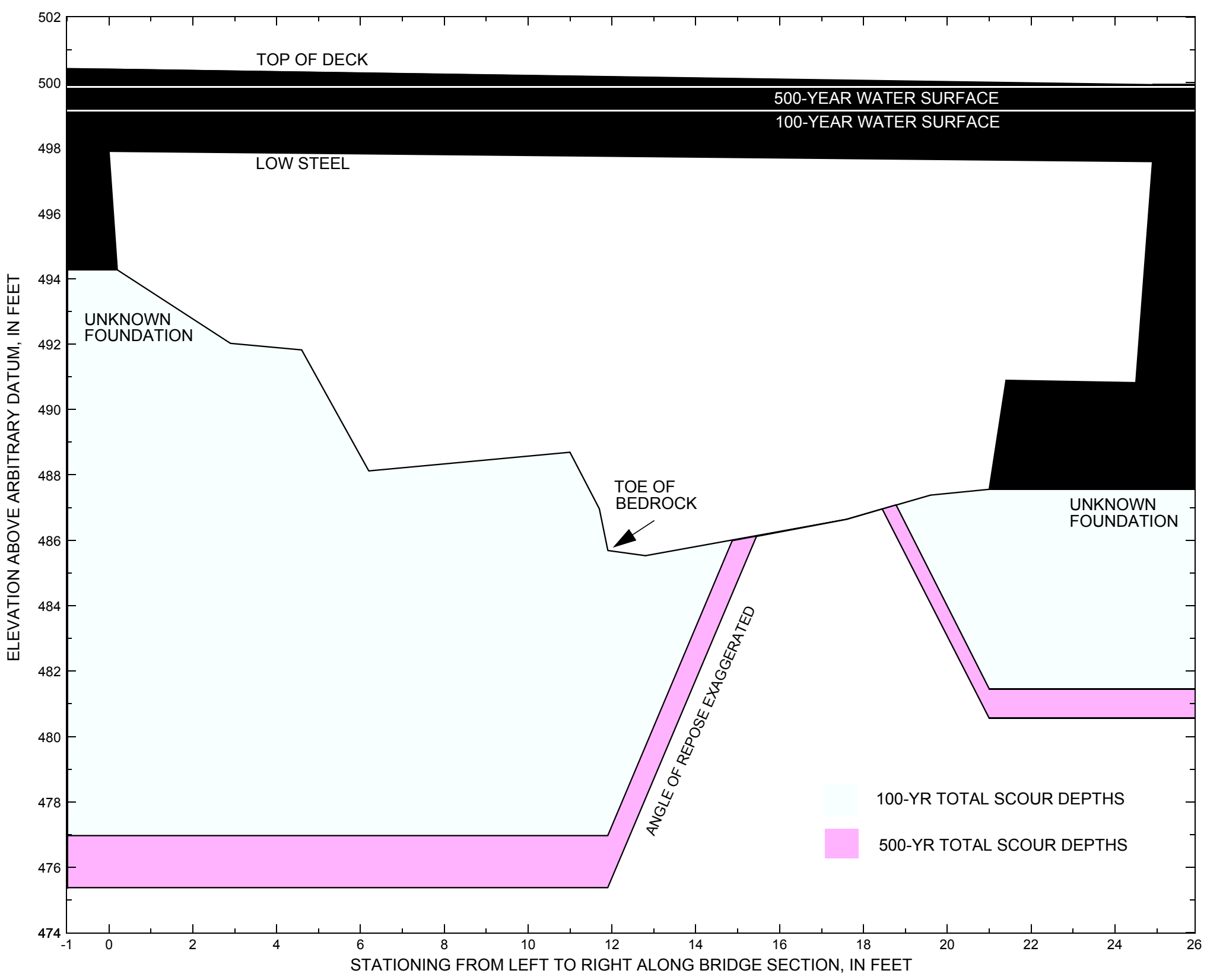

Figure 8. Scour elevations for the 100-yr and 500-yr discharges at structure NEWBTH00500065 on Town Highway 50, crossing Peach Brook, Newbury, Vermont. 
Table 1. Remaining footing/pile depth at abutments for the 100-year discharge at structure NEWBTH00500065 on Town Highway 50, crossing Peach Brook, Newbury, Vermont.

[VTAOT, Vermont Agency of Transportation; --, no data]

\begin{tabular}{|c|c|c|c|c|c|c|c|c|c|c|c|}
\hline Description & Station $^{1}$ & $\begin{array}{l}\text { VTAOT } \\
\text { minimum } \\
\text { low-chord } \\
\text { elevation } \\
\text { (feet) }\end{array}$ & $\begin{array}{l}\text { Surveyed } \\
\text { minimum } \\
\text { low-chord } \\
\text { elevation } \\
\text { (feet) }\end{array}$ & $\begin{array}{l}\text { VTAOT } \\
\text { bottom of } \\
\text { footing } \\
\text { elevation } \\
\text { (feet) }\end{array}$ & $\begin{array}{c}\text { Channel } \\
\text { elevation at } \\
\text { abutment/ } \\
\text { pier }^{2} \\
\text { (feet) }\end{array}$ & $\begin{array}{l}\text { Contraction } \\
\text { scour depth } \\
\text { (feet) }\end{array}$ & $\begin{array}{l}\text { Abutment } \\
\text { scour } \\
\text { depth } \\
\text { (feet) }\end{array}$ & $\begin{array}{l}\text { Pier } \\
\text { scour } \\
\text { depth } \\
\text { (feet) }\end{array}$ & $\begin{array}{l}\text { Depth of } \\
\text { total scour } \\
\text { (feet) }\end{array}$ & $\begin{array}{c}\text { Elevation of } \\
\text { scour }^{2} \\
\text { (feet) }\end{array}$ & $\begin{array}{c}\text { Remaining } \\
\text { footing/pile } \\
\text { depth } \\
\text { (feet) }\end{array}$ \\
\hline \multicolumn{12}{|c|}{100 -yr. discharge is 2,880 cubic-feet per second } \\
\hline Left abutment & 0.0 & -- & 497.9 & 485.5 & 494.3 & -- & -- & -- & -- & -- & -- \\
\hline Toe of bedrock & 11.9 & -- & -- & -- & 485.7 & 0.0 & 8.7 & -- & 8.7 & 477.0 & -- \\
\hline Right abutment & 24.9 & -- & 497.6 & 485.5 & 487.6 & 0.0 & 6.1 & -- & 6.1 & 481.5 & -- \\
\hline
\end{tabular}

- 1.Measured along the face of the most constricting side of the bridge.

2.Arbitrary datum for this study.

Table 2. Remaining footing/pile depth at abutments for the 500-year discharge at structure NEWBTH00500065 on Town Highway 50, crossing Peach Brook, Newbury, Vermont.

[VTAOT, Vermont Agency of Transportation; --, no data]

\begin{tabular}{|c|c|c|c|c|c|c|c|c|c|c|c|}
\hline Description & Station $^{1}$ & $\begin{array}{l}\text { VTAOT } \\
\text { minimum } \\
\text { low-chord } \\
\text { elevation } \\
\text { (feet) }\end{array}$ & $\begin{array}{c}\text { Surveyed } \\
\text { minimum } \\
\text { low-chord } \\
\text { elevation } \\
\text { (feet) }\end{array}$ & $\begin{array}{l}\text { VTAOT } \\
\text { bottom of } \\
\text { footing } \\
\text { elevation } \\
\text { (feet) }\end{array}$ & $\begin{array}{c}\text { Channel } \\
\text { elevation at } \\
\text { abutment/ } \\
\text { pier }^{2} \\
\text { (feet) }\end{array}$ & $\begin{array}{l}\text { Contraction } \\
\text { scour depth } \\
\text { (feet) }\end{array}$ & $\begin{array}{l}\text { Abutment } \\
\text { scour } \\
\text { depth } \\
\text { (feet) }\end{array}$ & $\begin{array}{l}\text { Pier } \\
\text { scour } \\
\text { depth } \\
\text { (feet) }\end{array}$ & $\begin{array}{l}\text { Depth of } \\
\text { total scour } \\
\text { (feet) }\end{array}$ & $\begin{array}{c}\text { Elevation of } \\
\text { scour }^{2} \\
\text { (feet) }\end{array}$ & $\begin{array}{c}\text { Remaining } \\
\text { footing/pile } \\
\text { depth } \\
\text { (feet) }\end{array}$ \\
\hline \multicolumn{12}{|c|}{500 -yr. discharge is 4,300 cubic-feet per second } \\
\hline Left abutment & 0.0 & -- & 497.9 & 485.5 & 494.3 & -- & -- & -- & -- & -- & -- \\
\hline Toe of bedrock & 11.9 & -- & -- & -- & 485.7 & 0.0 & 10.3 & -- & 10.3 & 475.4 & -- \\
\hline Right abutment & 24.9 & -- & 497.6 & 485.5 & 487.6 & 0.0 & 7.0 & -- & 7.0 & 480.6 & -- \\
\hline
\end{tabular}

1.Measured along the face of the most constricting side of the bridge.

2.Arbitrary datum for this study. 


\section{SELECTED REFERENCES}

Arcement, G.J., Jr., and Schneider, V.R., 1989, Guide for selecting Manning's roughness coefficients for natural channels and flood plains: U.S. Geological Survey Water-Supply Paper 2339, 38 p.

Barnes, H.H., Jr., 1967, Roughness characteristics of natural channels: U.S. Geological Survey Water-Supply Paper 1849,213 p.

Benson, M. A., 1962, Factors Influencing the Occurrence of Floods in a Humid Region of Diverse Terrain: U.S. Geological Survey WaterSupply Paper 1580-B, 64 p.

Brown, S.A. and Clyde, E.S., 1989, Design of riprap revetment: Federal Highway Administration Hydraulic Engineering Circular No. 11, Publication FHWA-IP-89-016, 156 p.

Federal Highway Administration, 1983, Runoff estimates for small watersheds and development of sound design: Federal Highway Administration Report FHWA-RD-77-158.

Federal Highway Administration, 1993, Stream Stability and Scour at Highway Bridges: Participant Workbook: Federal Highway Administration Report FHWA-HI-91-011.

Froehlich, D.C., 1989, Local scour at bridge abutments in Ports, M.A., ed., Hydraulic Engineering--Proceedings of the 1989 National Conference on Hydraulic Engineering: New York, American Society of Civil Engineers, p. 13-18.

Hayes, D.C.,1993, Site selection and collection of bridge-scour data in Delaware, Maryland, and Virginia: U.S. Geological Survey WaterResources Investigation Report 93-4017, 23 p.

Interagency Advisory Committee on Water Data, 1982, Guidelines for determining flood flow frequency: U.S. Geological Survey, Bulletin 17B of the Hydrology Subcommittee, 190 p.

Johnson, C.G. and Tasker, G.D.,1974, Progress report on flood magnitude and frequency of Vermont streams: U.S. Geological Survey OpenFile Report 74-130, 37 p.

Lagasse, P.F., Schall, J.D., Johnson, F., Richardson, E.V., Chang, F., 1995, Stream Stability at Highway Structures: Federal Highway Administration Hydraulic Engineering Circular No. 20, Publication FHWA-IP-90-014, 144 p.

Laursen, E.M., 1960, Scour at bridge crossings: Journal of the Hydraulics Division, American Society of Civil Engineers, v. 86, no. HY2, p. 39-53.

Potter, W. D., 1957a, Peak rates of runoff in the Adirondack, White Mountains, and Maine woods area, Bureau of Public Roads

Potter, W. D., 1957b, Peak rates of runoff in the New England Hill and Lowland area, Bureau of Public Roads

Richardson, E.V. and Davis, S.R., 1995, Evaluating scour at bridges: Federal Highway Administration Hydraulic Engineering Circular No. 18, Publication FHWA-IP-90-017, 204 p.

Richardson, E.V., Simons, D.B., and Julien, P.Y., 1990, Highways in the river environment: Federal Highway Administration Publication FHWA-HI-90-016.

Ritter, D.F., 1984, Process Geomorphology: W.C. Brown Co., Debuque, Iowa, 603 p.

Shearman, J.O., 1990, User's manual for WSPRO--a computer model for water surface profile computations: Federal Highway Administration Publication FHWA-IP-89-027, 187 p.

Shearman, J.O., Kirby, W.H., Schneider, V.R., and Flippo, H.N., 1986, Bridge waterways analysis model; research report: Federal Highway Administration Publication FHWA-RD-86-108, 112 p.

Talbot, A.N., 1887, The determination of water-way for bridges and culverts.

U.S. Department of Transportation, 1993, Stream stability and scour at highway bridges, Participant Workbook: Federal Highway Administration Publication FHWA HI-91-011.

U.S. Geological Survey, 1973, Newbury, Vermont 7.5 Minute Series quadrangle map: U.S. Geological Survey Topographic Maps, Scale 1:24,000. 


\section{APPENDIX A: \\ WSPRO INPUT FILE}




\section{WSPRO INPUT FILE}

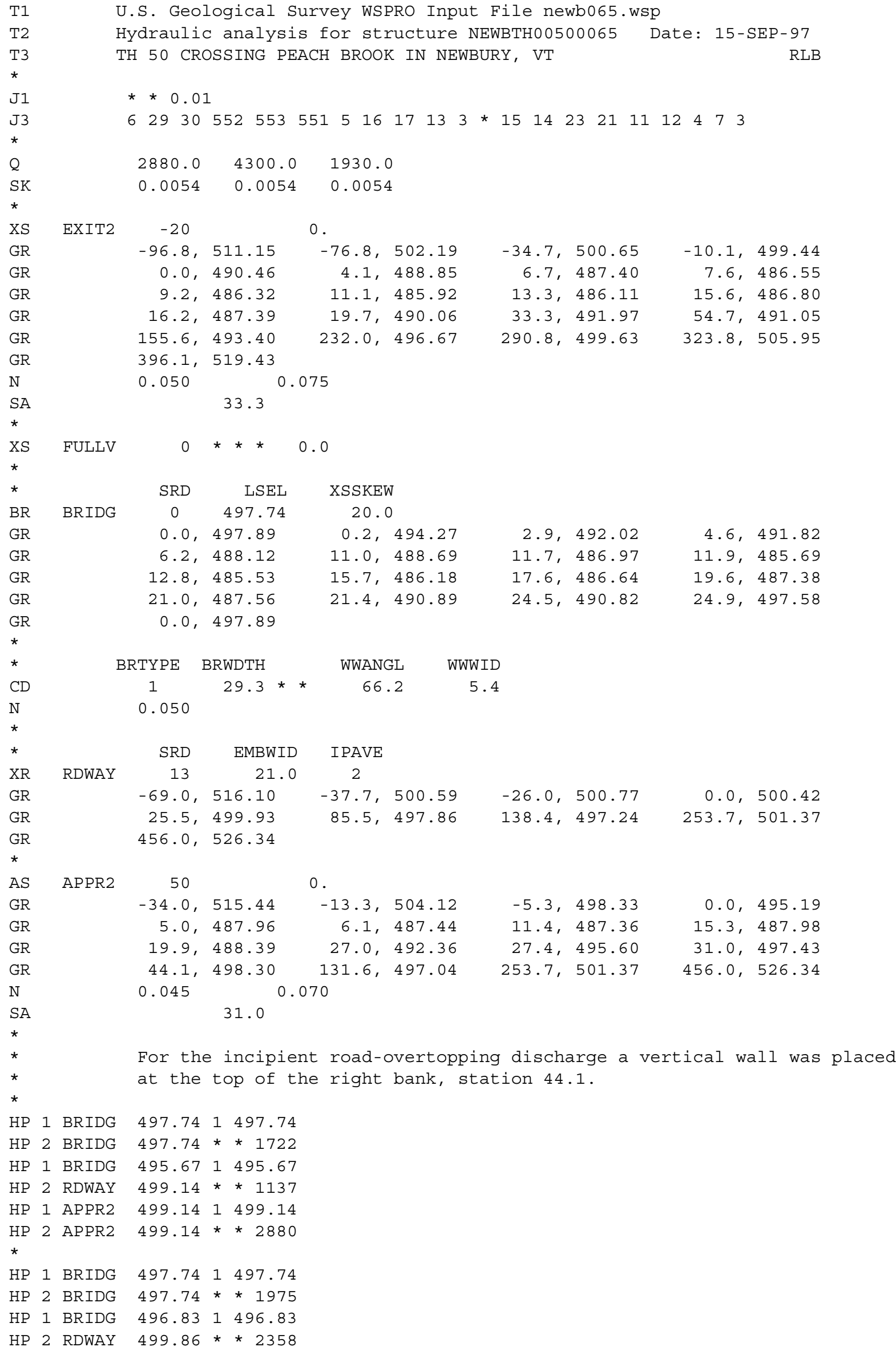




\section{APPENDIX B: \\ WSPRO OUTPUT FILE}




\title{
WSPRO OUTPUT FILE
}

\author{
U.S. Geological Survey WSPRO Input File newb065.wsp \\ Hydraulic analysis for structure NEWBTH00500065 Date: 15-SEP-97 \\ TH 50 CROSSING PEACH BROOK IN NEWBURY, VT \\ *** RUN DATE \& TIME: 10-22-97 14:35 \\ CROSS-SECTION PROPERTIES: $\quad$ ISEQ $=3 ; \quad$ SECID $=$ BRIDG $; \quad$ SRD $=0$.

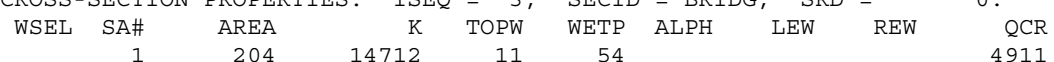

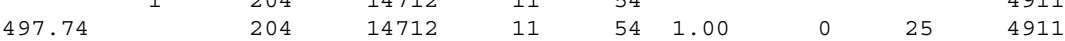 \\ VELOCITY DISTRIBUTION: ISEQ $=3 ;$ SECID $=$ BRIDG; $\quad$ SRD $=0$.

\begin{tabular}{|c|c|c|c|c|c|c|c|c|c|c|c|}
\hline & & JSEL & LEW & REW & ARE & & $\mathrm{K}$ & $Q$ & VEL & & \\
\hline & 497 & .74 & 0.0 & 24.9 & 203. & 9 & 4712 . & 1722 . & 8.45 & & \\
\hline $\mathrm{X}$ & STA. & 0.0 & & 3.6 & & 5.5 & & 6.7 & 7.5 & & 8.4 \\
\hline & $A(I)$ & & 15.5 & & 11.6 & & 10.0 & 7.7 & & 7.6 & \\
\hline & $V(I)$ & & 5.56 & & 7.39 & & 8.61 & 11.20 & & 1.29 & \\
\hline $\mathrm{x}$ & STA. & 8.4 & & 9.2 & & 10.1 & & 0.9 & 12.1 & & 12.8 \\
\hline & $A(I)$ & & 7.4 & & 7.2 & & 7.1 & 11.4 & & 8.3 & \\
\hline & $V(I)$ & & 11.70 & & 11.94 & & 2.13 & 7.56 & & 0.42 & \\
\hline $\mathrm{x}$ & STA. & 12.8 & & 13.5 & & 14.3 & & 5.0 & 15.9 & & 16.7 \\
\hline & $A(I)$ & & 8.2 & & 8.4 & & 8.8 & 8.9 & & 9.2 & \\
\hline & $V(I)$ & & 10.46 & & 10.29 & & 9.79 & 9.67 & & 9.34 & \\
\hline $\mathrm{x}$ & STA. & 16.7 & & 17.7 & & 18.7 & & 9.8 & 21.6 & & 24.9 \\
\hline & $A(I)$ & & 9.8 & & 10.3 & & 11.3 & 15.5 & & 19.8 & \\
\hline & $V(I)$ & & 8.81 & & 8.37 & & 7.61 & 5.56 & & 4.36 & \\
\hline & CROSS- & SECTION & PROPERT & IIES : & ISEQ & $=3 ;$ & SECID & $=$ BRIDG; & SRD & $=$ & 0 . \\
\hline & WSEL & SA\# & AREA & & K & TOPW & WETP & ALPH & LEW & REW & QCR \\
\hline & & 1 & 157 & & 1991 & 23 & 38 & & & & 2311 \\
\hline & 495.67 & & 157 & & 1991 & 23 & 38 & 1.00 & 0 & 25 & 2311 \\
\hline
\end{tabular} \\ VELOCITY DISTRIBUTION: ISEQ $=4 ; \quad \operatorname{SECID}=$ RDWAY $; \quad \operatorname{SRD}=13$.

\begin{tabular}{|c|c|c|c|c|c|c|c|c|c|c|c|}
\hline & & JSEL & LEW & REW & ARE & $E A$ & $\mathrm{~K}$ & $Q$ & VEL & & \\
\hline & 499 & .14 & 48.4 & 191.4 & 158 & .3 & 3362 . & 1137. & 7.18 & & \\
\hline $\mathrm{X}$ & STA. & 48.4 & & 77.1 & & 85.4 & & .7 & 97.4 & & 102.5 \\
\hline & $A(I)$ & & 14.2 & & 9.4 & & 8.2 & 7.9 & & 7.4 & \\
\hline & $\mathrm{V}(\mathrm{I})$ & & 4.00 & & 6.02 & & 6.93 & 7.19 & & 7.71 & \\
\hline $\mathrm{x}$ & STA. & 102.5 & & 107.1 & & 111.5 & 115 & 5.7 & 119.6 & & 123.4 \\
\hline & $A(I)$ & & 7.0 & & 6.8 & & 6.7 & 6.5 & & 6.5 & \\
\hline & $\mathrm{V}(\mathrm{I})$ & & 8.09 & & 8.30 & & 8.44 & 8.76 & & 8.79 & \\
\hline $\mathrm{X}$ & STA. & 123.4 & & 127.0 & & 130.5 & 134 & .0 & 137.4 & & 141.0 \\
\hline & $A(I)$ & & 6.3 & & 6.3 & & 6.4 & 6.3 & & 6.7 & \\
\hline & $V(I)$ & & 9.00 & & 9.07 & & 8.93 & 8.97 & & 8.54 & \\
\hline $\mathrm{X}$ & STA. & 141.0 & & 144.8 & & 149.5 & 155 & 5.4 & 163.5 & & 191.4 \\
\hline & $A(I)$ & & 6.7 & & 7.4 & & 8.2 & 9.3 & & 13.9 & \\
\hline & $V(I)$ & & 8.50 & & 7.64 & & 6.93 & 6.09 & & 4.08 & \\
\hline & CROSS- & SECTION & PROPER? & TIES : & ISEQ & $=5 ;$ & SECID & $=$ APPR2; & SRD & $=$ & 50. \\
\hline & WSEL & SA\# & AREA & & $\mathrm{K}$ & TOPW & WETP & ALPH & LEW & REW & QCR \\
\hline & & 1 & 295 & & 3224 & 37 & 47 & & & & 4690 \\
\hline & & 2 & 208 & & 5255 & 160 & 160 & & & & 1342 \\
\hline & 499.14 & & 502 & & 8479 & 197 & 207 & 1.88 & -5 & 191 & 3311 \\
\hline
\end{tabular} \\ VELOCITY DISTRIBUTION: ISEQ $=5 ; \operatorname{SECID}=$ APPR2; $\quad$ SRD $=50$.

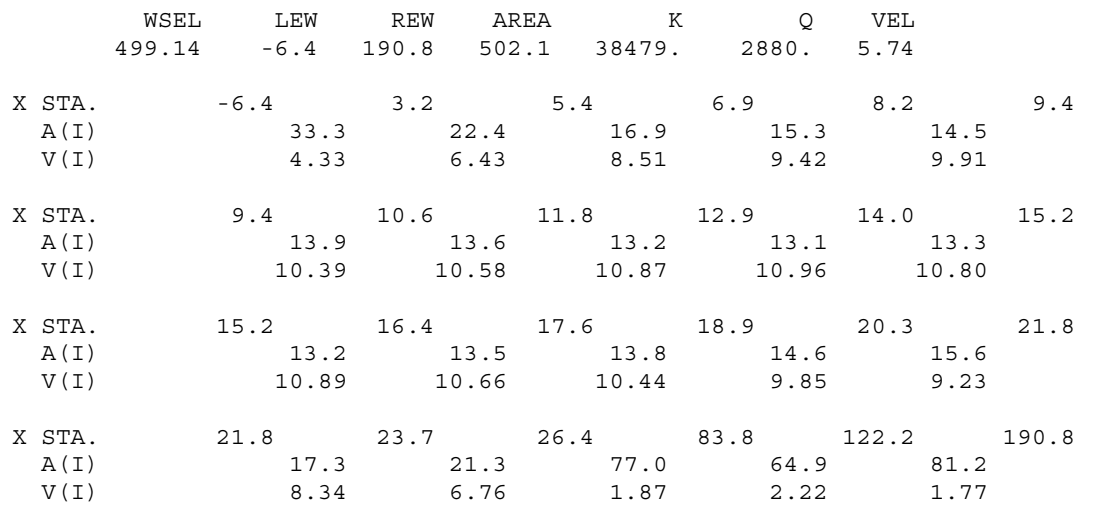


WSPRO OUTPUT FILE (continued)

\footnotetext{
U.S. Geological Survey WSPRO Input File newb065.wsp

Hydraulic analysis for structure NEWBTH00500065 Date: 15-SEP-97

TH 50 CROSSING PEACH BROOK IN NEWBURY, VT

*** RUN DATE \& TIME: 10-22-97 14:35

CROSS-SECTION PROPERTIES: $\quad$ ISEQ $=3 ; \quad$ SECID $=$ BRIDG $; \quad$ SRD $=0$.

WSEL SA\# AREA $\quad K$ TOPW WETP ALPH LEW REW

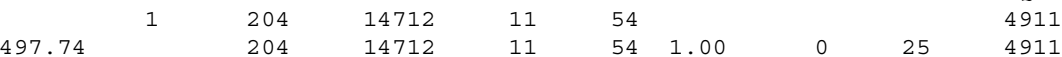

VELOCITY DISTRIBUTION: ISEQ $=3 ; \operatorname{SECID~}=$ BRIDG; $\operatorname{SRD}=\quad 0$.

\begin{tabular}{|c|c|c|c|c|c|c|c|c|c|c|c|}
\hline & & JSEL & LEW & REW & ARE & & $\mathrm{K}$ & $Q$ & VEL & & \\
\hline & 497 & .74 & 0.0 & 24.9 & 203. & 9 & 712. & 1975. & 9.69 & & \\
\hline X & STA. & 0.0 & & 3.6 & & 5.5 & & 6.7 & 7.5 & & 8.4 \\
\hline & $A(I)$ & & 15.5 & & 11.6 & & 0.0 & 7.7 & & 7.6 & \\
\hline & $V(I)$ & & 6.37 & & 8.48 & & .88 & 12.84 & & 2.95 & \\
\hline $\mathrm{x}$ & STA. & 8.4 & & 9.2 & & 10.1 & & 0.9 & 12.1 & & 12.8 \\
\hline & $A(I)$ & & 7.4 & & 7.2 & & 7.1 & 11.4 & & 8.3 & \\
\hline & $V(I)$ & & 13.42 & & 13.70 & & .91 & 8.67 & & 1.96 & \\
\hline $\mathrm{X}$ & STA. & 12.8 & & 13.5 & & 14.3 & & 5.0 & 15.9 & & 16.7 \\
\hline & $A(I)$ & & 8.2 & & 8.4 & & 8.8 & 8.9 & & 9.2 & \\
\hline & $V(I)$ & & 12.00 & & 11.80 & & .22 & 11.09 & & 0.71 & \\
\hline X & STA. & 16.7 & & 17.7 & & 18.7 & & 9.8 & 21.6 & & 24.9 \\
\hline & $A(I)$ & & 9.8 & & 10.3 & & 1.3 & 15.5 & & 19.8 & \\
\hline & $V(I)$ & & 10.10 & & 9.59 & & .73 & 6.38 & & 5.00 & \\
\hline & CROSS - & SECTION & PROPERT & IIES: & ISEQ & $=3 ;$ & SECID & $=$ BRIDG; & SRD & $=$ & 0 \\
\hline & WSEL & SA\# & AREA & & K & TOPW & WETP & ALPH & LEW & REW & QCR \\
\hline & & 1 & 184 & & 5018 & 23 & 40 & & & & 2925 \\
\hline & 496.83 & & 184 & & 5018 & 23 & 40 & 1.00 & 0 & 25 & 2925 \\
\hline
\end{tabular}

VELOCITY DISTRIBUTION: $\operatorname{ISEQ}=4 ; \operatorname{SECID}=$ RDWAY $; \quad \operatorname{SRD}=13$.

\begin{tabular}{|c|c|c|c|c|c|c|c|c|c|c|c|}
\hline & & NSEL & LEW & REW & $\mathrm{ARI}$ & REA & K & Q & VEL & & \\
\hline & 49 & 9.86 & 27.5 & 211.5 & 276 & 5.0 & 7314. & 2358. & 8.54 & & \\
\hline $\mathrm{x}$ & STA. & 27.5 & & 64.6 & & 75.7 & & 3.6 & 90.1 & & 96.2 \\
\hline & $A(I)$ & & 23.7 & & 16.3 & & 14.2 & 13.1 & & 12.8 & \\
\hline & $V(I)$ & & 4.97 & & 7.21 & & 8.33 & 9.00 & & 9.20 & \\
\hline $\mathrm{X}$ & STA. & 96.2 & & 101.8 & & 107.0 & 11 & 2.1 & 116.9 & & 121.5 \\
\hline & $A(I)$ & & 11.9 & & 11.6 & & 11.6 & 11.2 & & 11.1 & \\
\hline & $V(I)$ & & 9.88 & & 10.12 & & 10.14 & 10.55 & & 10.64 & \\
\hline $\mathrm{X}$ & STA. & 121.5 & & 126.1 & & 130.5 & 13 & 4.9 & 139.1 & & 143.8 \\
\hline & $A(I)$ & & 11.2 & & 11.0 & & 11.2 & 11.1 & & 11.8 & \\
\hline & $\mathrm{V}(\mathrm{I})$ & & 10.57 & & 10.68 & & 10.54 & 10.63 & & 9.98 & \\
\hline $\mathrm{X}$ & STA. & 143.8 & & 149.0 & & 155.3 & 16 & 3.1 & 174.3 & & 211.5 \\
\hline & $A(I)$ & & 12.0 & & 13.5 & & 14.6 & 17.1 & & 24.9 & \\
\hline & $V(I)$ & & 9.81 & & 8.74 & & 8.06 & 6.90 & & 4.74 & \\
\hline & CROSS & -SECTION & PROPER & RTIES: & ISEQ & $=5 i$ & SECID & $=\mathrm{APPR} 2$ & SRD & $=$ & 50. \\
\hline & WSEL & SA\# & AREA & & K & TOPW & WETP & $\mathrm{ALPH}$ & LEW & REW & $\mathrm{QCR}$ \\
\hline & & 1 & 322 & & 7854 & 38 & 48 & & & & 5287 \\
\hline & & 2 & 330 & & 0508 & 180 & 180 & & & & 2533 \\
\hline & 499.86 & & 652 & & 8362 & 219 & 228 & 2.01 & -6 & 211 & 4509 \\
\hline
\end{tabular}

VELOCITY DISTRIBUTION: ISEQ $=5 ;$ SECID $=$ APPR2; $\operatorname{SRD}=50$.

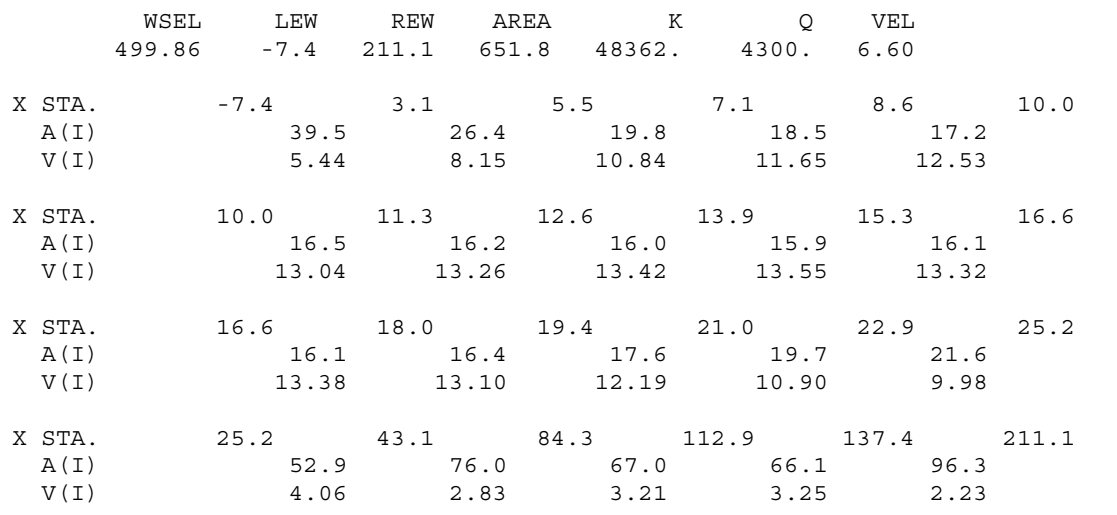


WSPRO OUTPUT FILE (continued)

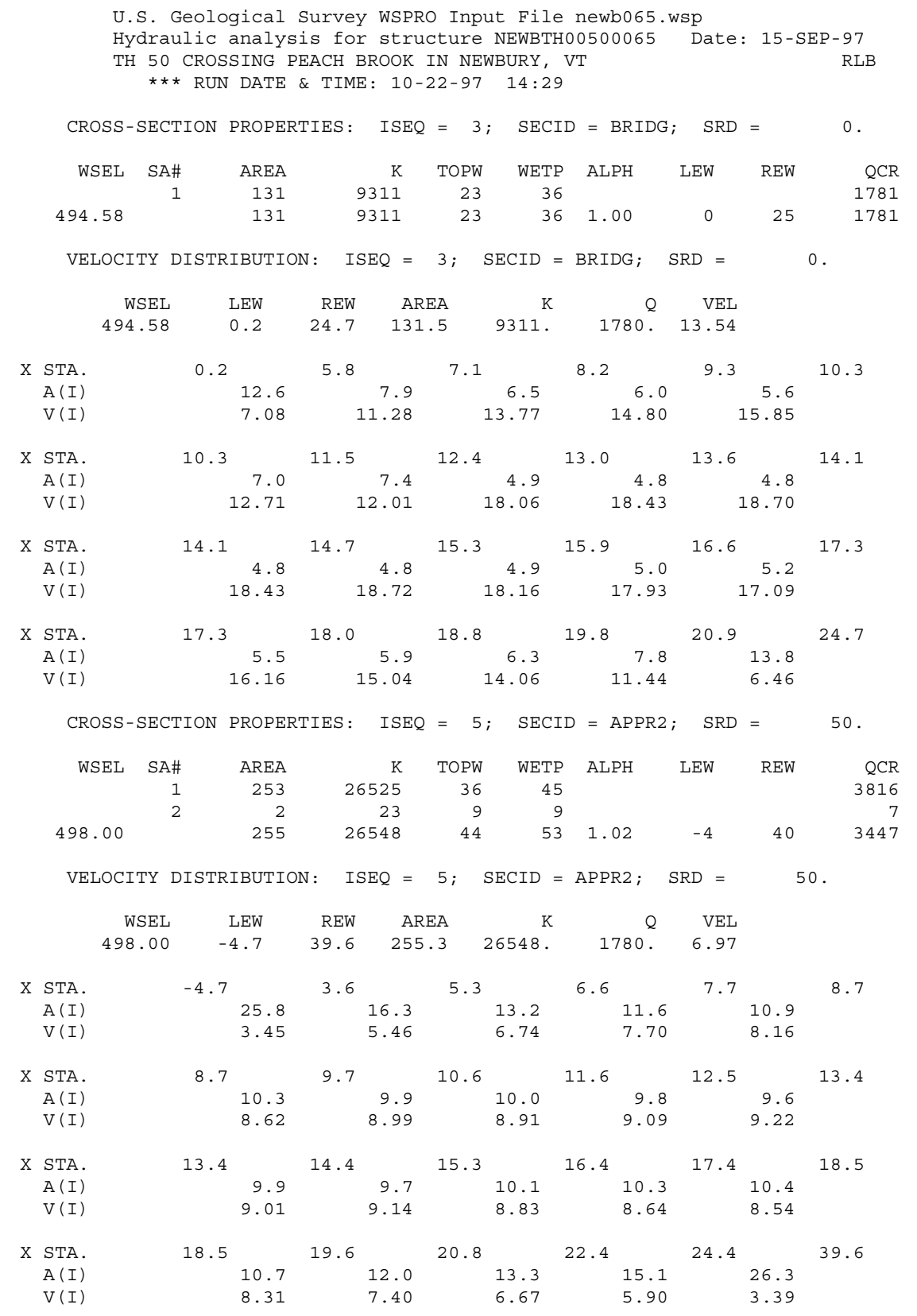


WSPRO OUTPUT FILE (continued)

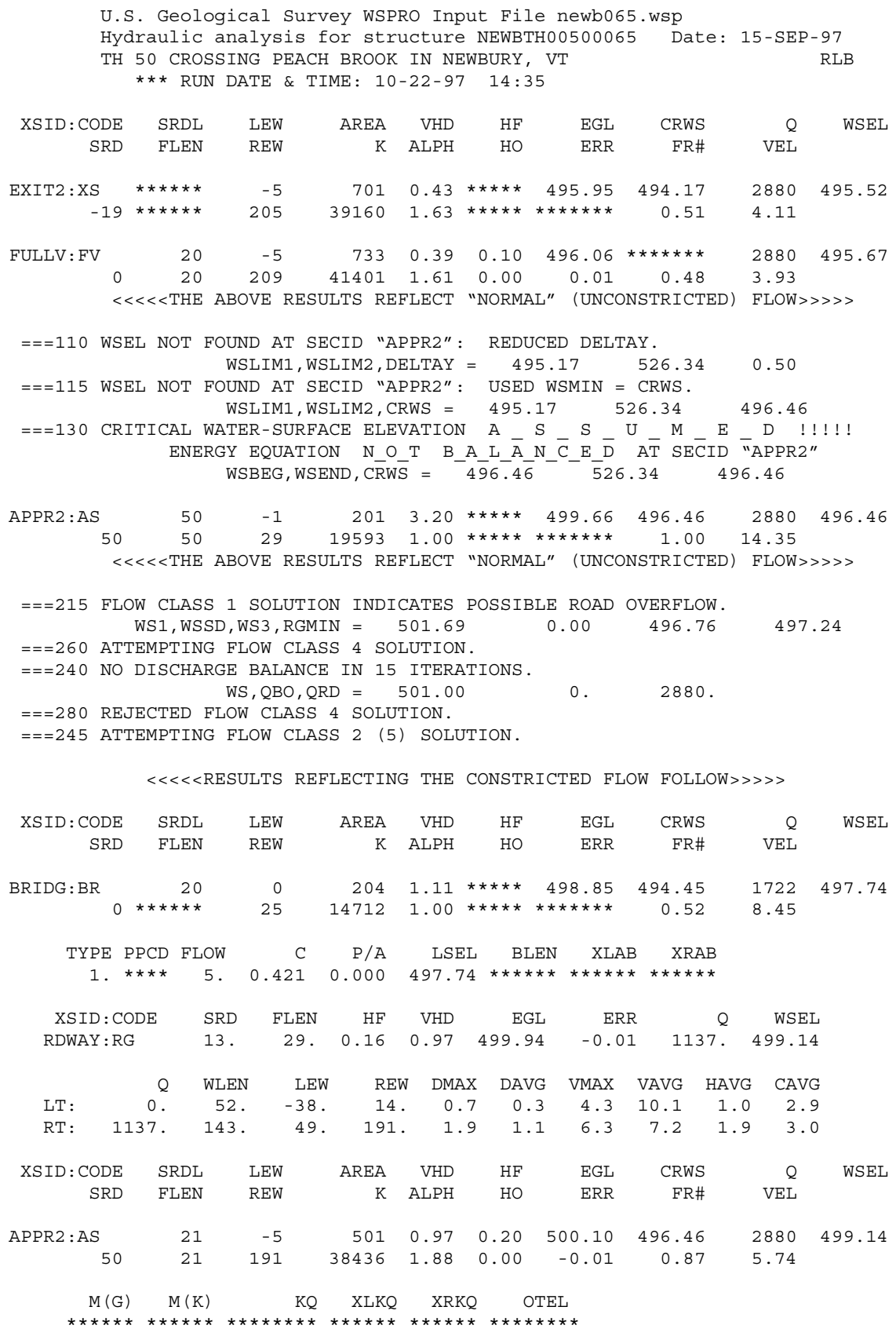

$<<<<$ END OF BRIDGE COMPUTATIONS $>>>>>$

FIRST USER DEFINED TABLE.

\begin{tabular}{|c|c|c|c|c|c|c|c|c|}
\hline XSID : CODE & SRD & LEW & REW & $Q$ & $\mathrm{~K}$ & AREA & VEL & WSEL \\
\hline EXIT2:XS & -20 & -6 & 205. & 2880 . & 39160 . & 701. & 4.11 & 495.52 \\
\hline FULLV : FV & 0 . & -6 . & 209. & 2880 . & 41401. & 733. & 3.93 & 495.67 \\
\hline BRIDG : BR & 0. & 0 & 25 & 1722. & 14712 . & 204 . & 8.45 & 497.74 \\
\hline RDWAY : RG & $13 . *$ & $\star \star \star \star \star *$ & 0 . & 1137. & \multicolumn{2}{|c|}{$0 . * * * * * * * * *$} & 2.00 & 499.14 \\
\hline APPR2 : AS & 50. & -6 & 191. & 2880 . & 38436 . & 501. & 5.74 & 499.14 \\
\hline XSID : CODE & XLKQ & $\mathrm{XRKQ}$ & & & & & & \\
\hline
\end{tabular}

SECOND USER DEFINED TABLE.

$\begin{array}{lcrrrrrrrr}\text { XSID : CODE } & \text { CRWS } & \text { FR\# } & \text { YMIN } & \text { YMAX } & \text { HF } & \text { HO } & \text { VHD } & \text { EGL } & \text { WSEL } \\ \text { EXIT2:XS } & 494.17 & 0.51 & 485.92 & 519.43 * * * * * * * * * * & 0.43 & 495.95 & 495.52 \\ \text { FULLV : FV } & * * * * * * * * & 0.48 & 485.92 & 519.43 & 0.10 & 0.00 & 0.39 & 496.06 & 495.67 \\ \text { BRIDG : BR } & 494.45 & 0.52 & 485.53 & 497.89 * * * * * * * * * * & 1.11 & 498.85 & 497.74 \\ \text { RDWAY : RG } & * * * * * * * * * * * * * * * * & 497.24 & 526.34 & 0.16 * * * * * * & 0.97 & 499.94 & 499.14 \\ \text { APPR2 : AS } & 496.46 & 0.87 & 487.36 & 526.34 & 0.20 & 0.00 & 0.97 & 500.10 & 499.14\end{array}$


WSPRO OUTPUT FILE (continued)

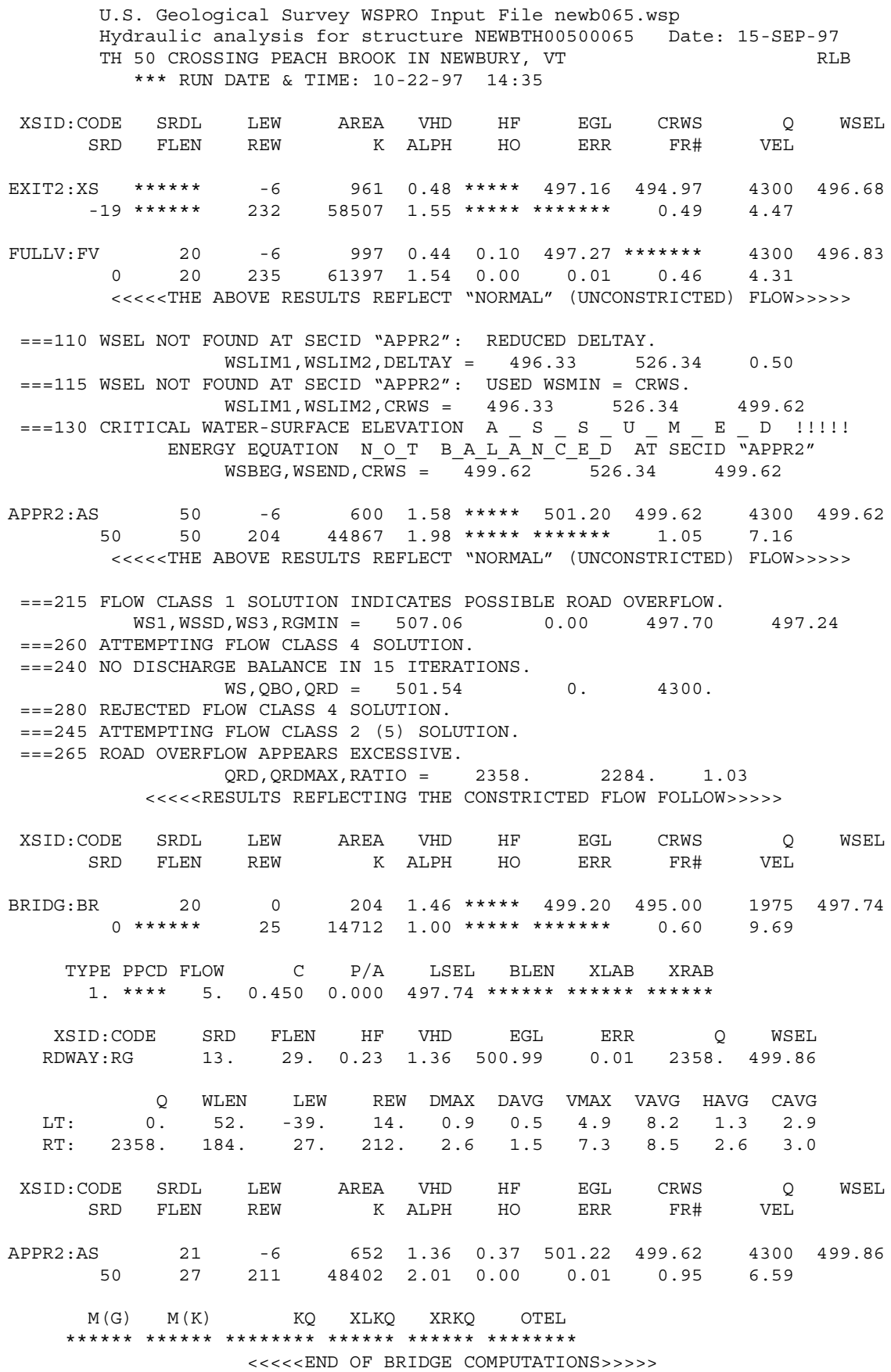


WSPRO OUTPUT FILE (continued)

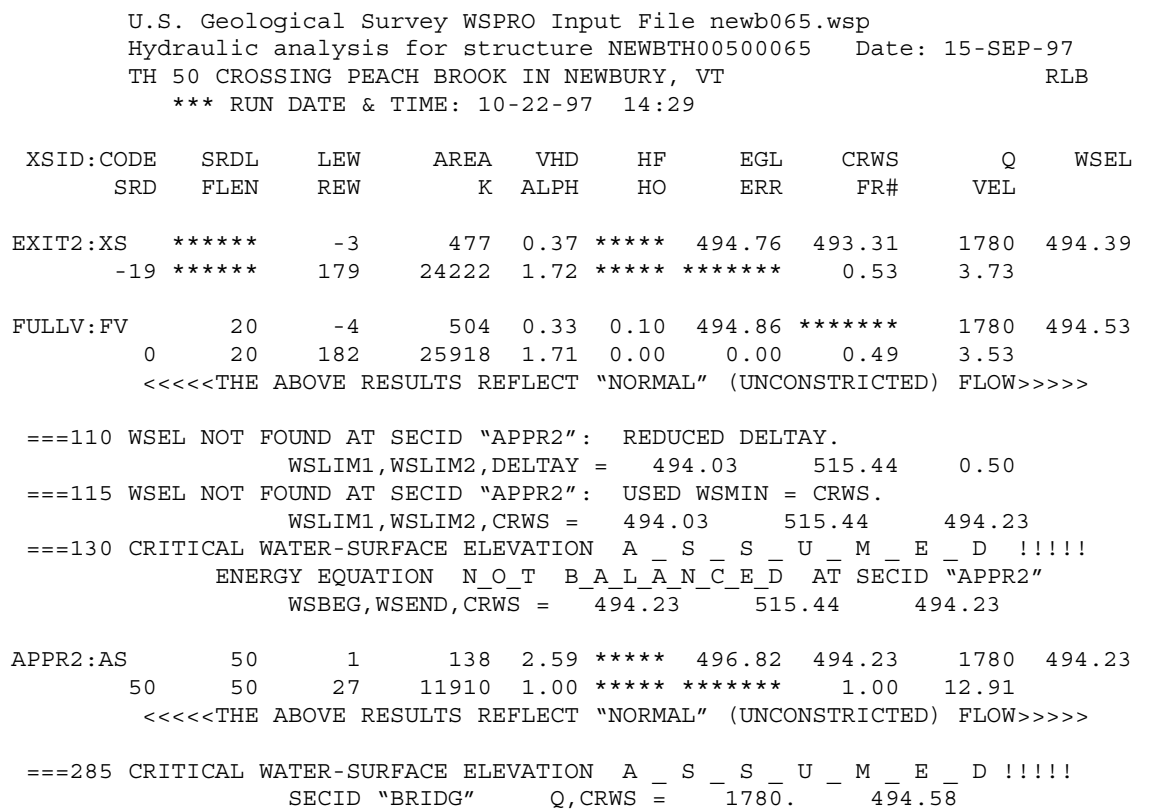

<<<<RESULTS REFLECTING THE CONSTRICTED FLOW FOLLOW $\gg>>>>$

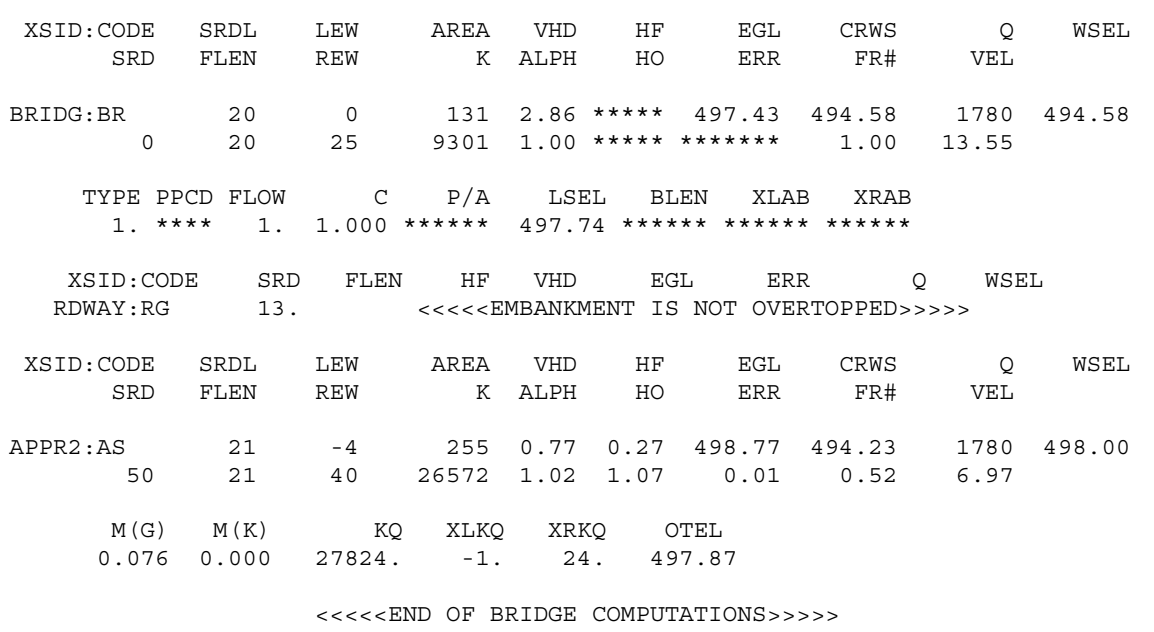

FIRST USER DEFINED TABLE.

\begin{tabular}{|c|c|c|c|c|c|c|c|c|}
\hline XSID : CODE & SRD & LEW & REW & Q & $\mathrm{K}$ & AREA & VEL & WSEI \\
\hline EXIT2:XS & -20 & -4 & 179. & 1780. & 24222 . & 477 . & 3.73 & 494.39 \\
\hline FULLV : FV & 0. & -5 . & 182. & 1780. & 25918 . & 504. & 3.53 & 494.53 \\
\hline BRIDG : BR & 0 & 0 & 25 . & 1780. & 9301. & 131. & 13.55 & 494.58 \\
\hline RDWAY : RG & \multicolumn{3}{|c|}{$13 . * * * * * * * * * * * * * *$} & \multicolumn{3}{|c|}{ 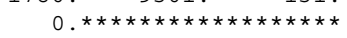 } & \multicolumn{2}{|c|}{$2.00 * * * * * * * *$} \\
\hline APPR $2:$ AS & 50. & -5 & 40 & 1780. & 26572 . & 255 . & 6.97 & 498.00 \\
\hline XSID : CODE & XLKQ & XRKQ & & & & & & \\
\hline APPR2 : AS & -1 & 24 & 27824 & & & & & \\
\hline
\end{tabular}

SECOND USER DEFINED TABLE.

\begin{tabular}{|c|c|c|c|c|c|c|c|c|c|}
\hline XSID : CODE & CRWS & FR\# & YMIN & YMAX & $\mathrm{HF}$ & $\mathrm{HO}$ & VHD & EGL & WSEL \\
\hline EXIT2:XS & 493.31 & 0.53 & 485.92 & 519.43 * & $\star * \star * * *$ & $\star \star \star \star \star \star ~$ & 0.37 & 494.76 & 494.39 \\
\hline FULLV : FV & 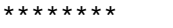 & 0.49 & 485.92 & 519.43 & 0.10 & 0.00 & 0.33 & 494.86 & 494.53 \\
\hline BRIDG : BR & 494.58 & 1.00 & 485.53 & $497.89 *$ & $\star * \star \star \star * *$ & $\star * * * *$ & 2.86 & 497.43 & 494.58 \\
\hline RDW & 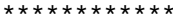 & $\star \star \star \star \star *$ & 498.30 & $516.10 *$ & $\star * \star * \star$ & 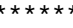 & 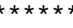 & $\star \star \star \star \star \star \star *$ & 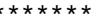 \\
\hline APPR2 : AS & 494.23 & 0.52 & 487.36 & 515.44 & 0.27 & 1.07 & 0.77 & 498.77 & 498.00 \\
\hline
\end{tabular}




\section{APPENDIX C:}

\section{BED-MATERIAL PARTICLE-SIZE DISTRIBUTION}




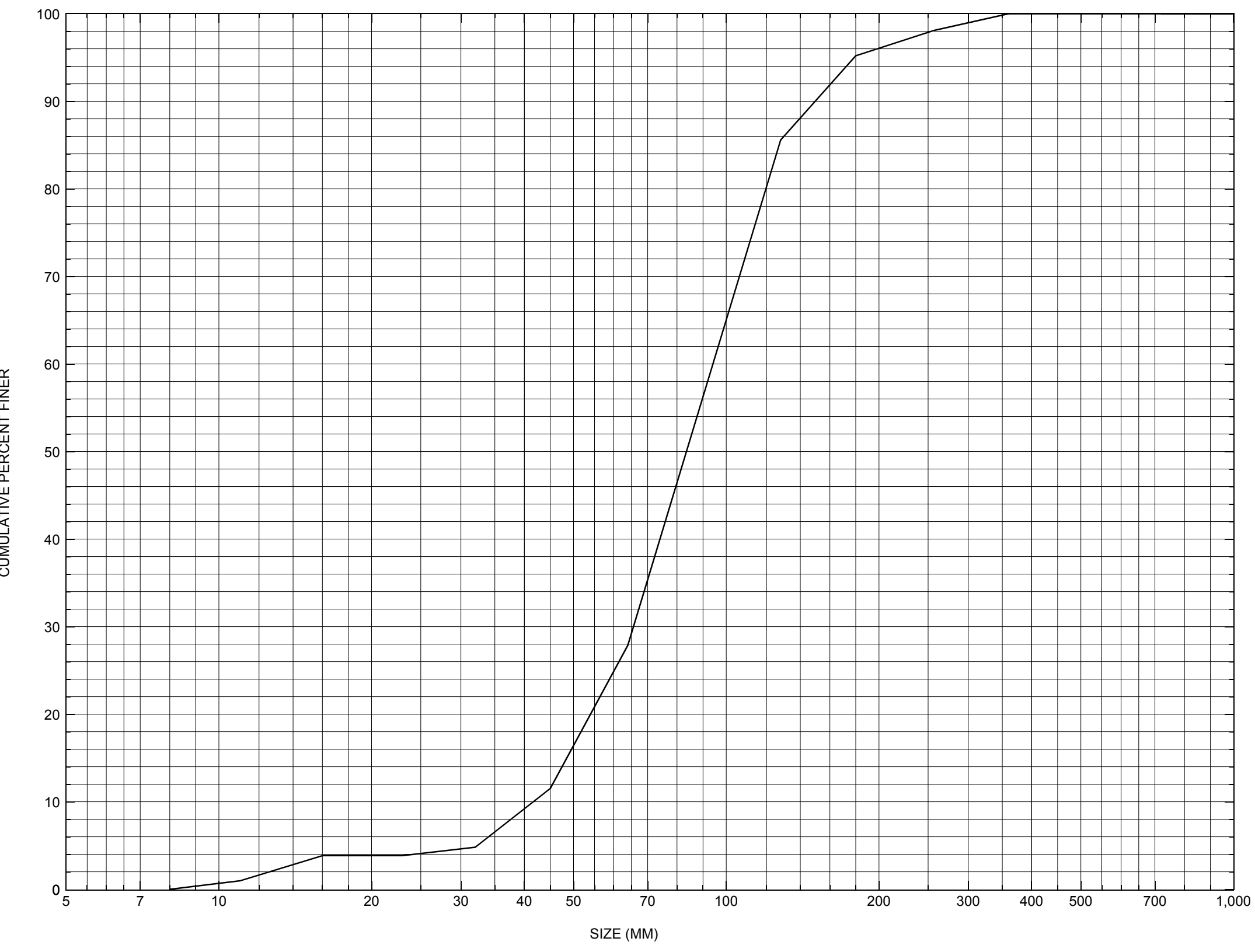

Appendix C. Bed material particle-size distribution for a pebble count in the channel approach of structure NEWBTH00500065, in Newbury, Vermont. 


\section{APPENDIX D: \\ HISTORICAL DATA FORM}




\section{Structure Number NEWBTH00500065}

\section{General Location Descriptive}

Data collected by (First Initial, Full last name) $\mathbf{E}$. BOEHMLER

Date $(M M / D D / Y Y) \_\mathbf{0 3} / \underline{27} / \underline{95}$

Highway District Number (I - 2; nn) $\mathbf{0 7}$

Town (FIPS place code; I - 4; nnnnn) $\mathbf{4 8 1 7 5}$

Waterway (I - 6) PEACH BROOK

Route Number $\underline{\text { TH050 }}$

Topographic Map Newbury

Latitude (I - 16; nnnn.n) $\mathbf{4 4 0 4 4}$
County (FIPS county code; I - 3; nnn) 17

Mile marker (I - 11; nnn.nnn) $\mathbf{0 0 0 0 0 0}$

Road Name (I - 7): -

Vicinity (I - 9) 0.6 MI JCT TH 50 + TH 55

Hydrologic Unit Code: $\mathbf{0 1 0 8 0 1 0 4}$

Longitude (i - 17; nnnnn.n) $\mathbf{7 2 0 5 8}$

\section{Select Federal Inventory Codes}

FHWA Structure Number $(I$ - 8) $\mathbf{1 0 0 9 0 7 0 0 6 5 0 9 0 7}$

Maintenance responsibility $(I-21 ; n n) \quad \mathbf{0 3}$

Year built (I - 27; YYYY) 1953

Average daily traffic, ADT (I - 29; nnnnnn) 000200

Year of ADT (I - 30; YY) $\mathbf{9 3}$

Opening skew to Roadway $(I-34 ; n n) \quad \mathbf{2 2}$

Operational status $(I-41 ; X) \quad \mathbf{P}$

Structure type (I - 43; nnn) 101

Approach span structure type (I - 44; nnn) $\mathbf{0 0 0}$

Number of spans (I - 45; nnn) $\underline{\mathbf{0 0 1}}$

Number of approach spans (I - 46; nnnn) $\mathbf{0 0 0 0}$

Comments:

The structural inspection report of 10/11/93 indicates that the structure is a concrete slab type bridge. The abutment walls and wingwalls are concrete, which have minor fine cracks and small spalls reported overall. The right abutment has a large diagonal settlement crack reported on its upstream half. Four large concrete blocks are reported as having been placed in front of the upstream right wingwall and the upstream end of the right abutment along with stone fill in an effort to prevent further erosion and settlement. The left abutment has a vertical crack reported just upstream of its center. The left abutment is resting on bedrock with some stone fill around its ends. There is stone fill reported (Continued, page 33) 


\section{Bridge Hydrologic Data}

Is there hydrologic data available? $\underline{\mathbf{N}}$ if No, type ctrl-n $h \quad$ VTAOT Drainage area $\left(m i^{2}\right)$ : -

Terrain character:

Stream character \& type: -

Streambed material:

Discharge Data (cfs):

$$
\begin{aligned}
& \mathrm{Q}_{2.33}- \\
& \mathrm{Q}_{50}
\end{aligned}
$$

Record flood date $(M M / D D / Y Y)$ :

Estimated Discharge (cfs): Ice conditions (Heavy, Moderate, Light) : -

$$
\mathrm{Q}_{10} \frac{-}{\mathrm{Q}_{100}-}
$$$$
\mathrm{Q}_{25} \ldots
$$

Water surface elevation (ft): $(\mathrm{ft} / \mathrm{s}):$

The stage increases to maximum highwater elevation (Rapidly, Not rapidly):

The stream response is (Flashy, Not flashy):

Describe any significant site conditions upstream or downstream that may influence the stream's stage: -

Watershed storage area (in percent):

The watershed storage area is: - (1-mainly at the headwaters; 2- uniformly distributed; 3-immediatly upstream oi the site)

Water Surface Elevation Estimates for Existing Structure:

\begin{tabular}{|l|l|l|l|l|l|}
\hline Peak discharge frequency & $Q_{2.33}$ & $Q_{10}$ & $Q_{25}$ & $Q_{50}$ & $Q_{100}$ \\
Water surface elevation (ft)) & - & - & - & - & - \\
Velocity (ft/sec) & - & - & - & - & - \\
\hline
\end{tabular}

Long term stream bed changes: -

Is the roadway overtopped below the $\mathrm{Q}_{100}$ ? (Yes, No, Unknown): $\mathbf{U}$ Frequency: Relief Elevation $(f t)$ : Discharge over roadway at $Q_{100}\left(f t^{3} / \mathrm{sec}\right)$ :

Are there other structures nearby? (Yes, No, Unknown): Upstream distance (miles): Town: If No or Unknown, type ctrl-n os Highway No. :Structure No. : Year Built:

Clear span (ft): Clear Height $(f t)$ : Full Waterway $\left(f^{2}\right)$ : 
Downstream distance (miles): Town: Year Built:

Highway No. : Structure No. : Structure Type:

Clear span (ft): Clear Height $(f t)$ : Full Waterway $\left(f t^{2}\right)$ :

Comments:

on all of the wingwalls. Bedrock is clearly exposed in the photographs of the left bank upstream and is reportedly exposed elsewhere along the channel edges downstream.

\section{USGS Watershed Data}

Watershed Hydrographic Data

Drainage area (DA) 15.32

Watershed storage (ST)

Bridge site elevation

Main channel length

600
$\mathrm{mi}^{2}$ 1 7.66 $10 \%$ channel length elevation $\quad \mathbf{6 2 0}$ Main channel slope (S) 46 $\mathrm{ft} / \mathrm{mi}$

Watershed Precipitation Data

Average site precipitation in Average headwater precipitation in

Maximum 2yr-24hr precipitation event $(124,2)$ in

Average seasonal snowfall (Sn) $\mathrm{ft}$ 


\section{Bridge Plan Data}

Are plans available? $\underline{Y}$ If no, type ctrl-n pl Date issued for construction (MM/YYYY): _ _ 1952 Project Number $\mathbf{T - 3 - 1 9 5 2}$

Minimum channel bed elevation: $\mathbf{4 8 9 . 0}$

Low superstructure elevation: USLAB N/A DSLAB N/A USRAB N/A DSRAB N/A
Benchmark location description:

BM\#1, spike in a root of an 18 inch elm tree, located about 70 feet to the right from the right abutment to the end of the upstream guardrail, then about 10 feet perpendicularly to the roadway centerline from the end of the guardrail toward the stream, upstream from the bridge, elevation 500.00.

Reference Point (MSL, Arbitrary, Other): Arbitrary $\quad$ Datum (NAD27, NAD83, Other): Arbitrary Foundation Type: 2

If 1: Footing Thickness _ _ Footing bottom elevation: -

If 2: Pile Type: 1 (1-Wood; 2-Steel or metal; 3-Concrete) Approximate pile driven length:

If 3: Footing bottom elevation: -

Is boring information available? $\quad \mathbf{N}$ If no, type ctrl-n bi Number of borings taken: -

Foundation Material Type: $\mathbf{3}$ (1-regolith, 2-bedrock, 3-unknown)

Briefly describe material at foundation bottom elevation or around piles:

NO FOUNDATION MATERIAL INFORMATION.

Comments:

No detail is provided on the low steel elevation. The bottom of the concrete section of the footings is $\mathbf{4 8 5 . 5}$ on the plans. There is very little detail provided on the plans. There are no points where the elevation might be used as a reference mark. 


\section{Cross-sectional Data}

Is cross-sectional data available? $\underline{\mathbf{Y}}$ If no, type ctrl-n xs

Source (FEMA, VTAOT, Other)? VTAOT

Orientation of the cross sections is inconsistent with any cross section data surveyed for this Comments: study and is not comparable. Data was not retrieved.

\begin{tabular}{|l|l|l|l|l|l|l|l|l|l|l|l|}
\hline Station & - & - & - & - & - & - & - & - & - & - & - \\
\hline Feature & - & - & - & - & - & - & - & - & - & - & - \\
\hline $\begin{array}{l}\text { Low chord } \\
\text { elevation }\end{array}$ & - & - & - & - & - & - & - & - & - & - & - \\
\hline $\begin{array}{l}\text { Bed } \\
\text { elevation }\end{array}$ & - & - & - & - & - & - & - & - & - & - & - \\
\hline $\begin{array}{l}\text { Low chord } \\
\text { to bed }\end{array}$ & - & - & - & - & - & - & - & - & - & - & - \\
\hline Station & - & - & - & - & - & - & - & - & - & - & - \\
\hline Feature & - & - & - & - & - & - & - & - & - & - & - \\
\hline $\begin{array}{l}\text { Low chord } \\
\text { elevation }\end{array}$ & - & - & - & - & - & - & - & - & - & - & - \\
\hline $\begin{array}{l}\text { Bed } \\
\text { elevation }\end{array}$ & - & - & - & - & - & - & - & - & - & - & - \\
\hline $\begin{array}{l}\text { Low chord } \\
\text { to bed }\end{array}$ & - & - & - & - & - & - & - & - & - & - & - \\
\hline
\end{tabular}

Source (FEMA, VTAOT, Other)?

Comments: -

\begin{tabular}{|l|l|l|l|l|l|l|l|l|l|l|l|}
\hline Station & - & - & - & - & - & - & - & - & - & - & - \\
\hline Feature & - & - & - & - & - & - & - & - & - & - & - \\
\hline $\begin{array}{l}\text { Low chord } \\
\text { elevation }\end{array}$ & - & - & - & - & - & - & - & - & - & - & - \\
\hline $\begin{array}{l}\text { Bed } \\
\text { elevation }\end{array}$ & - & - & - & - & - & - & - & - & - & - & - \\
\hline $\begin{array}{l}\text { Low chord } \\
\text { to bed }\end{array}$ & - & - & - & - & - & - & - & - & - & - & - \\
\hline Station & - & - & - & - & - & - & - & - & - & - & - \\
\hline Feature & - & - & - & - & - & - & - & - & - & - & - \\
\hline $\begin{array}{l}\text { Low chord } \\
\text { elevation }\end{array}$ & - & - & - & - & - & - & - & - & - & - & - \\
\hline $\begin{array}{l}\text { Bed } \\
\text { elevation }\end{array}$ & - & - & - & - & - & - & - & - & - & - & - \\
\hline $\begin{array}{l}\text { Low chord } \\
\text { to bed }\end{array}$ & - & - & - & - & - & - & - & - & - & - & - \\
\hline
\end{tabular}




\section{APPENDIX E: \\ LEVEL I DATA FORM}


U. S. Geological Survey

Bridge Field Data Collection and Processing Form

Qa/Qc Check by: EW Date: $\underline{\mathbf{0 3} / \mathbf{0 8} / \mathbf{9 6}}$

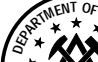

\section{Structure Number NEWBTH00500065}

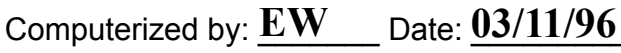

Reviewd by: $\quad$ RB Date: $\underline{10 / 28 / 97}$

\section{A. General Location Descriptive}

1. Data collected by (First Initial, Full last name) T. SEVERANCE

Date $(M M / D D / Y Y)$

$08 / 29$

11995

2. Highway District Number $\mathbf{0 7}$

County ORANGE (17)

Waterway $(I$ - 6) PEACH BROOK

Route Number $\mathbf{T H 0 5 0}$

3. Descriptive comments:

Located 0.6 miles from the junction of TH50 and TH55.
Mile marker -

Town NEWBURY (48175)

Road Name -

Hydrologic Unit Code: $\mathbf{0 1 0 8 0 1 0 4}$

\section{B. Bridge Deck Observations}
4. Surface cover... LBUS 6
RBUS 6
LBDS 5
RBDS 5
Overall 6

(2b us,ds,lb,rb: 1- Urban; 2- Suburban; 3- Row crops; 4- Pasture; 5- Shrub- and brushland; 6- Forest; 7- Wetland)
5. Ambient water surface...US $\underline{2}$
UB 1
DS 1
(1- pool; 2- riffle)

6. Bridge structure type 1 (1- single span; 2- multiple span; 3- single arch; 4- multiple arch; 5-cylindrical culvert; 6- box culvert; or 7- other)
7. Bridge length $\underline{29}$
(feet)
Span length 25
(feet)
Bridge width 21

\section{Road approach to bridge:}

\section{LB 2 RB 1 ( 0 even, 1-lower, 2- higher) \\ 9. LB 2 RB 2 (1- Paved, 2- Not paved)}

10. Embankment slope (run / rise in feet / foot):

US left

US right

\begin{tabular}{|c|c|c|c|}
\hline \multicolumn{2}{|c|}{ Protection } & \multirow{2}{*}{ 13.Erosion } & 14.Severity \\
\hline 11.Type & 12.Cond. & $\mathbf{0}$ & - \\
\hline $\mathbf{0}$ & - & $\mathbf{0}$ & - \\
$\mathbf{1}$ & $\mathbf{1}$ & $\mathbf{0}$ & - \\
\hline $\mathbf{0}$ & - & $\mathbf{0}$ & - \\
\hline $\mathbf{0}$ & - & $\mathbf{2}$ & $\mathbf{1}$ \\
\hline
\end{tabular}

Bank protection types: 0- none; 1- < 12 inches;

2- < 36 inches; 3- < 48 inches;

4- < 60 inches; 5- wall / artificial levee

Bank protection conditions: 1- good; 2- slumped;

3- eroded; 4- failed

Erosion: 0 - none; 1- channel erosion; 2-

road wash; 3- both; 4- other

Erosion Severity: 0 - none; 1- slight; 2- moderate; 3- severe

\section{Channel approach to bridge (BF):}

15. Angle of approach: $\mathbf{2 0}$

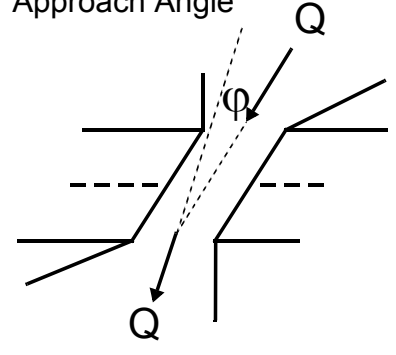

17. Channel impact zone 1 :

Where? LB $(L B, R B)$

Range? 40 feet US

Channel impact zone 2:

Where? - $\quad(L B, R B)$

Range? - $\quad$ feet -

(US, UB, DS) to -

Impact Severity: 0- none to very slight; 1- Slight; 2- Moderate; 3- Severe feet -

16. Bridge skew: $\mathbf{5 0}$ Bridge Skew Angle

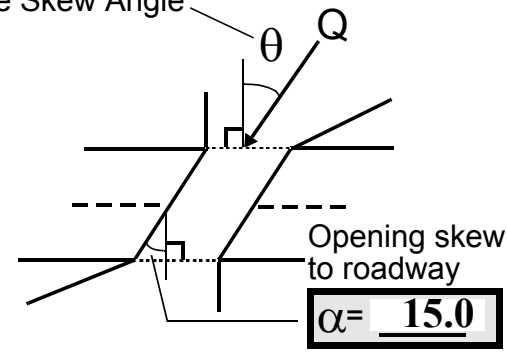

\section{Exist? $\mathbf{Y}(Y$ or $N)$}

Severity 2

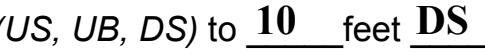

Exist? $\mathbf{N} \quad($ Yor $N)$

Severity - 
18. Bridge Type: 1a

1a- Vertical abutments with wingwalls

$1 \mathrm{~b}$ - Vertical abutments without wingwalls

2- Vertical abutments and wingwalls, sloping embankment Wingwalls parallel to abut. face

3- Spill through abutments

4- Sloping embankment, vertical wingwalls and abutments

Wingwall angle less than $90^{\circ}$.

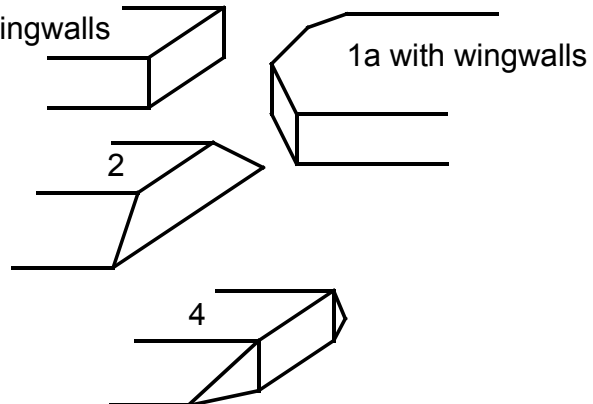

19. Bridge Deck Comments (surface cover variations, measured bridge and span lengths, bridge type variations, approach overflow width, etc.)

\#4: There are small trees on the DS banks in addition to the bushes.

\#7: Values are from the VTAOT database. Measured values are: bridge length= 28 feet; span length $=\mathbf{2 5 . 5}$ feet; and bridge width $=21$ feet.

\#8: The right road approach is lower than the bridge, but becomes higher after 3 bridge lengths. \#9: There is gravel over the concrete bridge deck.

\section{Upstream Channel Assessment}

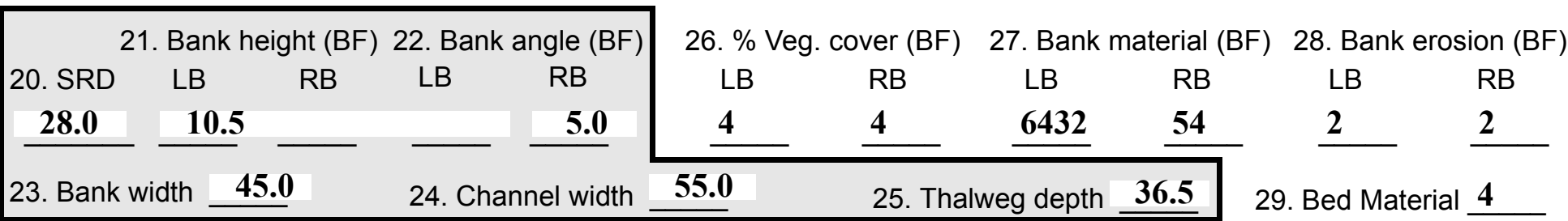

30 . Bank protection type: $\quad$ LB $\underline{\mathbf{0}}$ RB $\underline{\mathbf{2}}$

31. Bank protection condition: LB RB 1

SRD - Section ref. dist. to US face \% Vegetation (Veg) cover: 1- 0 to 25\%; 2- 26 to 50\%; 3- 51 to $75 \%$; 4- 76 to $100 \%$

Bed and bank Material: 0- organics; 1- silt / clay, <1/16mm; 2- sand, 1/16 - 2mm; 3- gravel, 2 - 64mm;

4- cobble, 64 - 256mm; 5- boulder, > 256mm; 6- bedrock; 7-manmade

Bank Erosion: 0- not evident; 1- light fluvial; 2- moderate fluvial; 3- heavy fluvial / mass wasting

Bank protection types: 0- absent; 1- < 12 inches; 2- < 36 inches; 3- < 48 inches; 4- < 60 inches; 5- wall / artificial levee

Bank protection conditions: 1-good; 2- slumped; 3- eroded; 4- failed

32. Comments (bank material variation, minor inflows, protection extent, etc.):

\#27: There is a large bedrock outcrop at 40 feet US of the left abutment that extends under the bridge.

\#28: On the LB, erosion has exposed much of bedrock. The sediment overlying the bedrock has been washed away exposing the root systems of the trees on the bank. The most severe erosion is at 50 feet US where the bank material (sand, gravel, cobble) is washing out. 
33.Point/Side bar present? $\mathbf{Y}(Y$ or $N$. if $N$ type ctrl-n pb)34. Mid-bar distance: $\mathbf{7 0}$ 35. Mid-bar width: $\mathbf{3}$

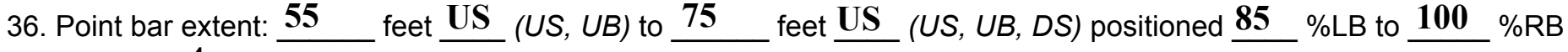

37. Material: 4

38. Point or side bar comments (Circle Point or Side; Note additional bars, material variation, status, etc.):

39. Is a cut-bank present? $\underline{Y}$ (Y or if $N$ type ctrl-n cb)

40. Where? $\underline{\text { LB }}$ (LB or RB)

41. Mid-bank distance: 48

42. Cut bank extent: 10

40. Where?

43. Bank damage: 1

(1- eroded and/or creep; 2- slip failure; 3- block failure)

44. Cut bank comments (eg. additional cut banks, protection condition, etc.):

45. Is channel scour present? $\underline{\mathbf{Y}}$ (Y or if $N$ type ctrl-n cs) $\quad$ 46. Mid-scour distance: 18

47. Scour dimensions: Length $\underline{4}$ Width $\underline{3}$ Depth : $\underline{\mathbf{0 . 7 5}}$ Position $\underline{\mathbf{2 0}} \%$ LB to $\underline{\mathbf{8 0}} \%$ RB

48. Scour comments (eg. additional scour areas, local scouring process, etc.):

$-$

49. Are there major confluences? $\mathbf{N}$

51. Confluence 1: Distance -

Confluence 2: Distance -

52. Enters on -

Enters on -

54. Confluence comments (eg. confluence name):

NO MAJOR CONFLUENCES
50. How many? -

53. Type(1- perennial; 2- ephemeral)

Type (1-perennial; 2- ephemeral) ( $(L B$ or $R B)$ (LB or $R B$ )

(a)


65. Debris and Ice Is there debris accumulation?

(Yor $N)$ 66. Where? $\mathbf{N}$ (1- Upstream; 2- At bridge; 3- Both)

67. Debris Potential ( 1- Low; 2- Moderate; 3- High) 68. Capture Efficiency 2 (1-Low; 2- Moderate; 3- High) 69. Is there evidence of ice build-up? 2 Ice Blockage Potential $\mathbf{N}$ (1-Low; 2-Moderate; 3- High) 70. Debris and Ice Comments:

2

\#67: The debris potential is moderate because the surface cover US is forest and some trees are hanging over the channel on the left bank US.

\#68: There is moderate capture efficiency because of the constriction of the bridge opening.

\begin{tabular}{|l|c|c|c|c|c|c|c|c|}
\hline Abutments & $\begin{array}{c}\text { 71. Attack } \\
\angle \mathrm{BF})\end{array}$ & $\begin{array}{c}\text { 72. Slope } \\
\text { (Qmax) }\end{array}$ & $\begin{array}{c}\text { 73. Toe } \\
\text { loc. (BF) }\end{array}$ & $\begin{array}{c}\text { 74. Scour } \\
\text { Condition }\end{array}$ & $\begin{array}{c}\text { 75. Scour } \\
\text { depth }\end{array}$ & $\begin{array}{c}\text { 76. Exposure } \\
\text { depth }\end{array}$ & 77. Material & 78. Length \\
\hline LABUT & & $\mathbf{4 0}$ & $\mathbf{8 5}$ & $\mathbf{2}$ & $\mathbf{1}$ & $\mathbf{0 . 7 5}$ & $\mathbf{0}$ & $\mathbf{9 0 . 0}$ \\
\hline RABUT & $\mathbf{1}$ & - & $\mathbf{8 5}$ & & & $\mathbf{2}$ & $\mathbf{1}$ & $\mathbf{2 4 . 0}$ \\
\hline
\end{tabular}

Pushed: $L B$ or RB

Toe Location (Loc.): 0- even, 1- set back, 2- protrudes

Scour cond.: 0- not evident; 1- evident (comment); 2- footing exposed; 3-undermined footing; 4- piling exposed; 5- settled; 6- failed

Materials: 1- Concrete; 2- Stone masonry or drywall; 3- steel or metal; 4- wood

79. Abutment comments (eg. undermined penetration, unusual scour processes, debris, etc.):

0.75

0

1

\#75: The scour is $0.75 \mathrm{ft}$ deep at the center of the RABUT and at the DS end of the LABUT.

\#77: Most of the LABUT is poured over bedrock.

There is some accumulation of small branches and twigs in areas UB.

A point bar exists along the RABUT from 12 feet $\mathrm{UB}$ to 28 feet $\mathrm{UB}$, mid-bar distance is 25 feet, bar width is 8 feet, and it is composed of sand and some cobbles.

80. Wingwalls:

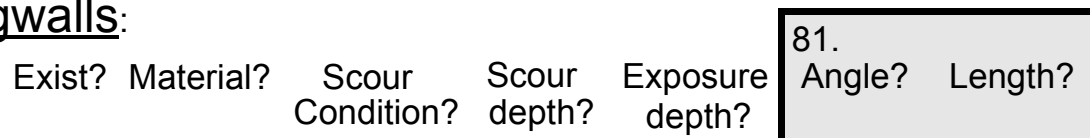

USLWW:

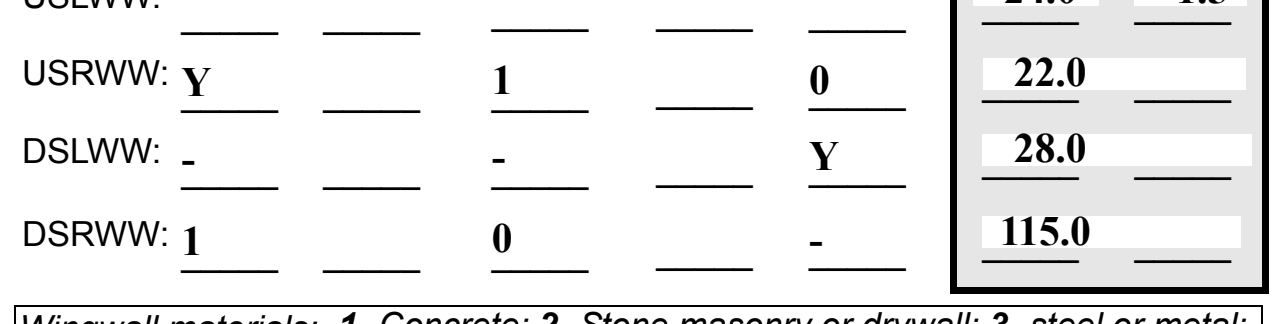

Wingwall materials: 1- Concrete; 2- Stone masonry or drywall; 3- steel or metal; 4- wood

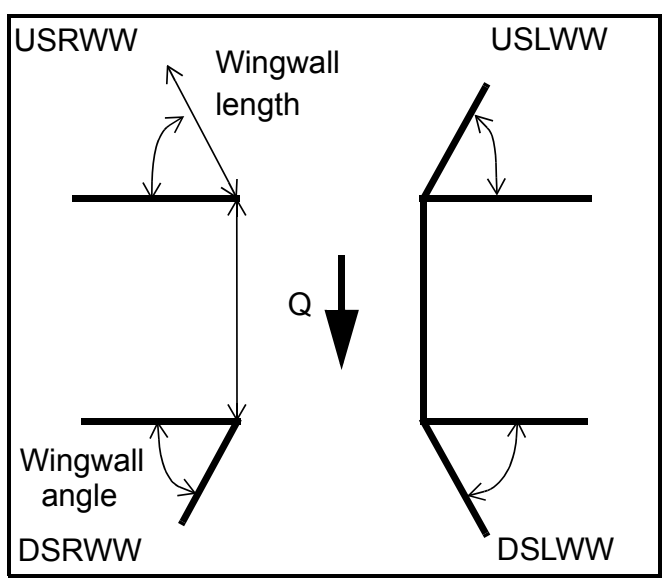

82. Bank / Bridge Protection:

\begin{tabular}{|l|l|l|l|l|l|l|l|c|}
\hline Location & USLWW & USRWW & LABUT & RABUT & LB & RB & DSLWW & DSRWW \\
\hline Type & - & $\mathbf{0}$ & $\mathbf{Y}$ & - & - & $\mathbf{1}$ & - & - \\
\hline Condition & $\mathbf{Y}$ & - & $\mathbf{1}$ & - & - & $\mathbf{1}$ & - & - \\
\hline Extent & $\mathbf{1}$ & - & $\mathbf{0}$ & $\mathbf{0}$ & $\mathbf{1}$ & $\mathbf{0}$ & $\mathbf{0}$ & - \\
\hline
\end{tabular}

Bank / Bridge protection types: 0- absent; 1- < 12 inches; 2- < 36 inches; 3- < 48 inches; 4- < 60 inches; 
83. Wingwall and protection comments (eg. undermined penetration, unusual scour processes, etc.):

-
-
-
-
2
1
1
1
2
2

Piers:

84. Are there piers? \#82 (Y or if $N$ type ctrl-n pr)

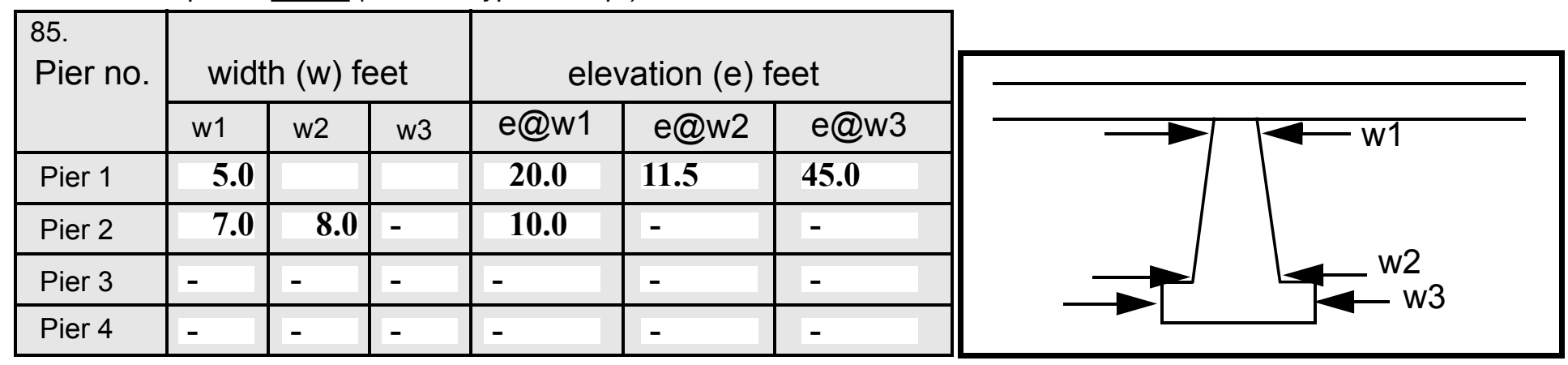

\begin{tabular}{|l|l|l|l|l|}
\hline Level 1 Pier Descr. & \multicolumn{1}{|c|}{1} & \multicolumn{1}{|c|}{2} & \multicolumn{1}{|c|}{3} & \multicolumn{1}{|c|}{4} \\
\hline 86. Location (BF) & The & g the & three 3 & g the \\
\hline 87. Type & USL & base & ft & entir \\
\hline 88. Material & WW & at & squa & e \\
\hline 89. Shape & is & the & re & base \\
\hline 90. Inclined? & con- & DS & con- & lengt \\
\hline 91. Attack $\angle$ (BF) & crete & end & crete & h. \\
\hline 92. Pushed & pour & of & bloc & An \\
\hline 93. Length (feet) & - & - & - & - \\
\hline 94. \# of piles & ed & the & ks & addi- \\
\hline 95. Cross-members & onto & USR & and & tiona \\
\hline 96. Scour Condition & bed- & WW & stone & I \\
\hline 97. Scour depth & rock. & there & fill & con- \\
\hline 98. Exposure depth & Alon & are & alon & crete \\
\hline
\end{tabular}

LFP, LTB, LB, MCL, MCM, MCR, RB, RTB, RFP

1- Solid pier, 2- column, 3- bent

1-Wood; 2-concrete; 3- metal; 4- stone

1- Round; 2- Square; 3- Pointed

Y-yes; $N-$ no

$L B$ or $R B$

0- none; 1- laterals; 2- diagonals; 3- both

0- not evident; 1- evident (comment);

2- footing exposed; 3- piling exposed;

4- undermined footing; 5- settled; 6- failed 
99. Pier comments (eg. undermined penetration, protection and protection extent, unusual scour processes, etc.):

block is at the US end of the RABUT.

$\mathbf{N}$

100.

\section{E. Downstream Channel Assessment}

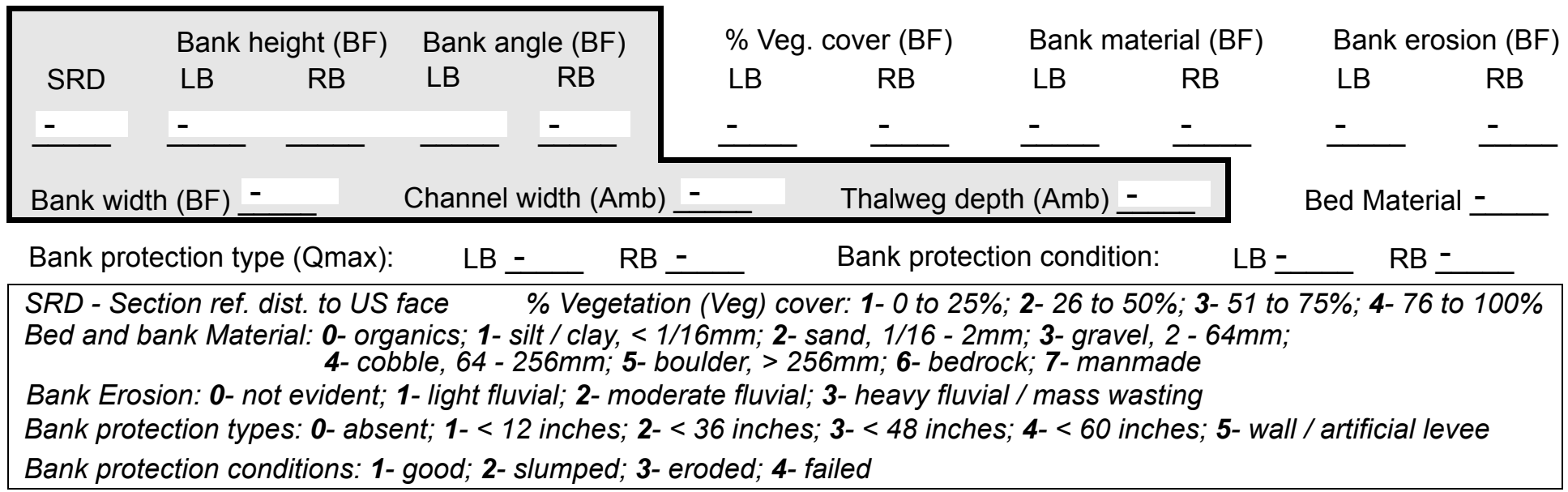

Comments (eg. bank material variation, minor inflows, protection extent, etc.):

$-$

$-$

$-$

$-$

$-$

$-$

$-$

$-$

$-$

$-$

$-$

$-$

$-$

$-$

$-$

101. Is a drop structure present? _ ( $Y$ or $N$, if $N$ type ctrl-n ds) 102. Distance: ___ feet 103. Drop: __ feet 104. Structure material: ___ (1- steel sheet pile; 2- wood pile; 3- concrete; 4- other) 105. Drop structure comments (eg. downstream scour depth):

$-$

$-$

$-$

$-$

$-$

$-$ 
106. Point/Side bar present? (Y or $N$. if $N$ type ctrl-n pb)Mid-bar distance:

Mid-bar width: -

Point bar extent: feet -

(US, UB, DS) to feet (US, UB, DS) positioned \%LB to $\%$ RB Material:

Point or side bar comments (Circle Point or Side; note additional bars, material variation, status, etc.):

S a cut-bank present? $\mathbf{N}$ (Y or if $N$ type ctrl-n cb) Where? $\underline{\mathbf{O}}$ (LB or RB) Mid-bank distance: PIE Cut bank extent: $\underline{\mathbf{R S}}$ feet __ (US, UB, DS) to feet __ (US, UB, DS)

Bank damage: (1- eroded and/or creep; 2- slip failure; 3- block failure)

Cut bank comments (eg. additional cut banks, protection condition, etc.):

Is channel scour present? ( $Y$ or if $N$ type ctrl-n cs) Width $\mathbf{0}$ Depth: $\mathbf{0}$

Mid-scour distance: $\mathbf{3}$ Scour dimensions: Length 3

Scour comments (eg. additional scour areas, local scouring process, etc.): 4 2 0 1

Are there major confluences? ( $Y$ or if $N$ type ctrl-n $m c)$ Confluence 1: Distance proEnters on tec- (LB or RB) Enters on the (LB or RB) Positioned 0 \%LB to 1 $\% \mathrm{RB}$

Confluence comments (eg. confluence name):

continues up the embankment at a 40 degree slope.

\section{F. Geomorphic Channel Assessment}

107. Stage of reach evolution
1- Constructed

2- Stable

3- Aggraded

4- Degraded

5- Laterally unstable

6- Vertically and laterally unstable 
108. Evolution comments (Channel evolution not considering bridge effects; See HEC-20, Figure 1 for geomorphic descriptors): 


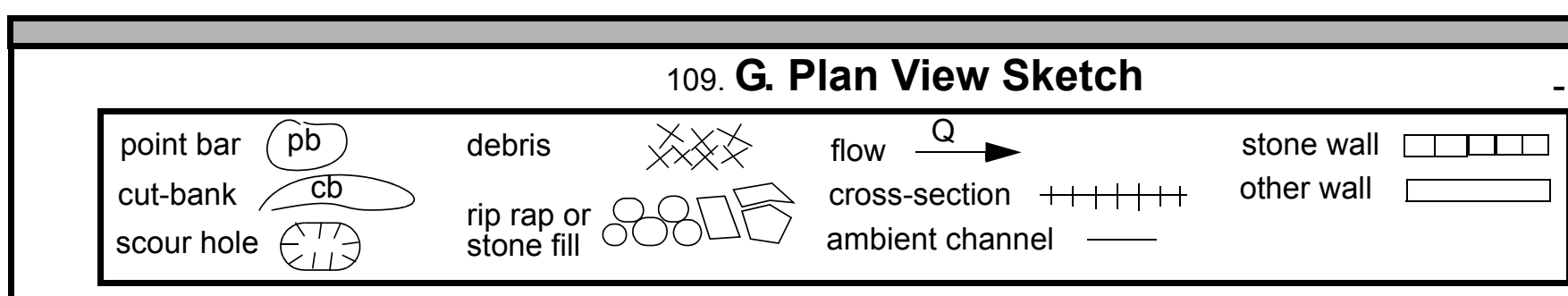


APPENDIX F:

SCOUR COMPUTATIONS 


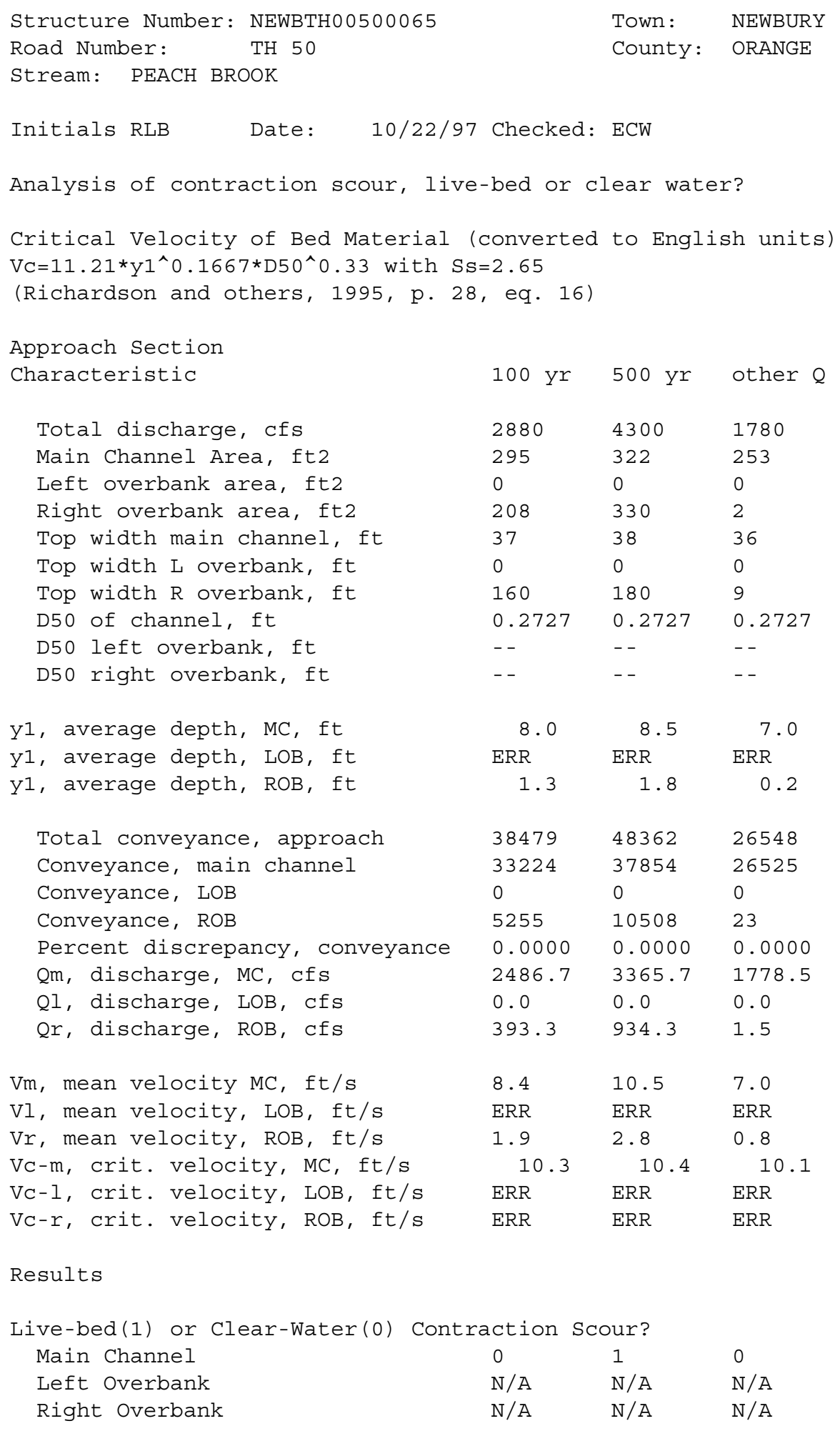




\begin{tabular}{|c|c|c|c|c|c|c|}
\hline \multicolumn{7}{|c|}{ 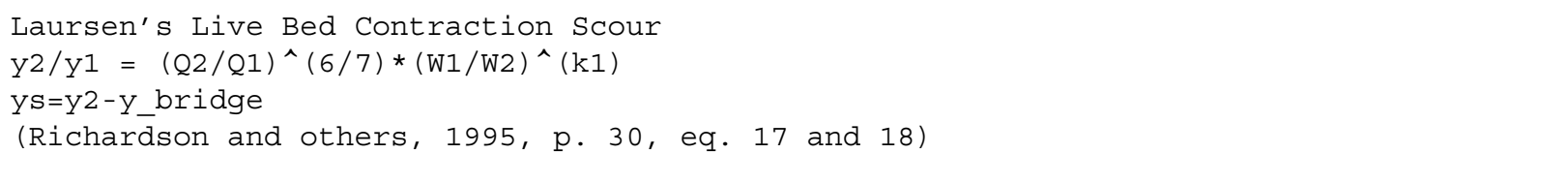 } \\
\hline & Approach & & & Bridge & & \\
\hline Characteristic & $100 \mathrm{yr}$ & $500 \mathrm{yr}$ & Other $Q$ & $100 \mathrm{yr}$ & $500 \mathrm{yr}$ & Other $Q$ \\
\hline Q1, discharge, cfs & 2880 & 4300 & 1780 & 0 & 1975 & 0 \\
\hline Total conveyance & 38479 & 48362 & 26548 & 0 & 14712 & 0 \\
\hline Main channel conveyance & 33224 & 37854 & 26525 & 0 & 14712 & 0 \\
\hline Main channel discharge & 2487 & 3366 & 1778 & $E R R$ & 1975 & ERR \\
\hline Area - main channel, ft2 & 295 & 322 & 253 & 0 & 204 & 0 \\
\hline (W1) channel width, ft & 37 & 38 & 36 & 0 & 23.4 & 0 \\
\hline (Wp) cumulative pier width, ft & 0 & 0 & 0 & 0 & 0 & 0 \\
\hline W1, adjusted bottom width(ft) & 37 & 38 & 36 & 0 & 23.4 & 0 \\
\hline D50, ft & 0.2727 & 0.2727 & 0.2727 & & & \\
\hline w, fall velocity, ft/s (p. 32) & 0 & 4.2725 & 0 & & & \\
\hline y, ave. depth flow, ft & 7.97 & 8.47 & 7.03 & $\mathrm{ERR}$ & 8.72 & ERR \\
\hline S1, slope EGL & 0 & 0.0786 & 0 & & & \\
\hline $\mathrm{P}$, wetted perimeter, $\mathrm{MC}$, ft & 0 & 48 & 0 & & & \\
\hline R, hydraulic Radius, ft & ERR & 6.708 & $\mathrm{ERR}$ & & & \\
\hline $\mathrm{V}^{*}$, shear velocity, ft/s & $\mathrm{N} / \mathrm{A}$ & 4.120 & $\mathrm{~N} / \mathrm{A}$ & & & \\
\hline $\mathrm{V} * / \mathrm{w}$ & ERR & 0.964 & ERR & & & \\
\hline $\begin{array}{l}\text { Bed transport coeff., } \mathrm{kl},(0.59 \mathrm{if} \\
\mathrm{k} 1\end{array}$ & $\begin{array}{l}\mathrm{V} * / \mathrm{W}<0.5 \\
0\end{array}$ & $\begin{array}{l}0.64 \text { if } \\
0.64\end{array}$ & $\begin{array}{c}.5<\mathrm{V} * / \mathrm{w}<2 \\
0\end{array}$ & ; 0.69 if & $\mathrm{V} * / \mathrm{w}>2.0$ & $0 \mathrm{p} .33)$ \\
\hline $\mathrm{y}^{2}$, depth in contraction, ft & ERR & 7.32 & ERR & & & \\
\hline ys, scour depth, ft (y2-y_bridge) & $\mathrm{N} / \mathrm{A}$ & -1.40 & $\mathrm{~N} / \mathrm{A}$ & & & \\
\hline
\end{tabular}

Clear water Contraction Scour in MAIN CHANNEL

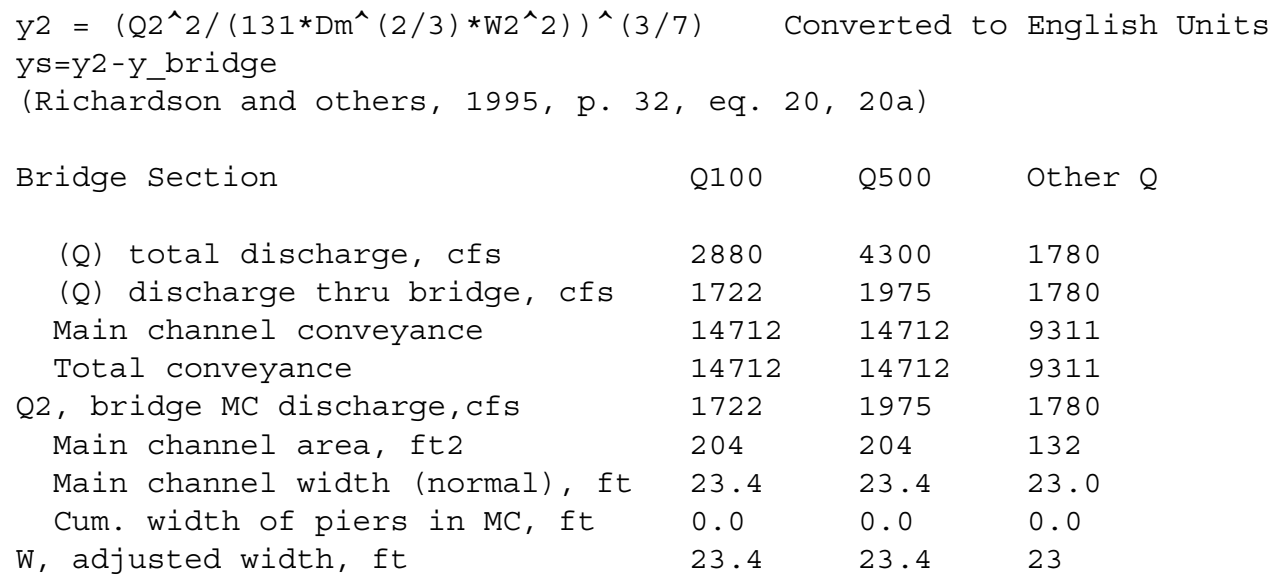




\begin{tabular}{|c|c|c|c|}
\hline Y_bridge (avg. depth at br.), ft & 8.71 & 8.71 & 5.72 \\
\hline Dm, median $(1.25 * D 50)$, ft & 0.340875 & 0.340875 & 0.340875 \\
\hline y2, depth in contraction, ft & 6.70 & 7.54 & 7.00 \\
\hline 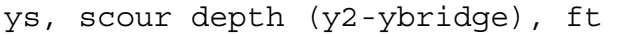 & 01 & .17 & 1.28 \\
\hline
\end{tabular}

Pressure Flow Scour (contraction scour for orifice flow conditions)

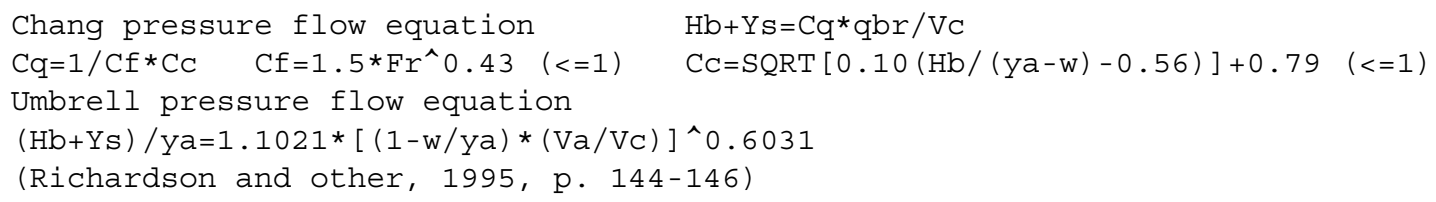




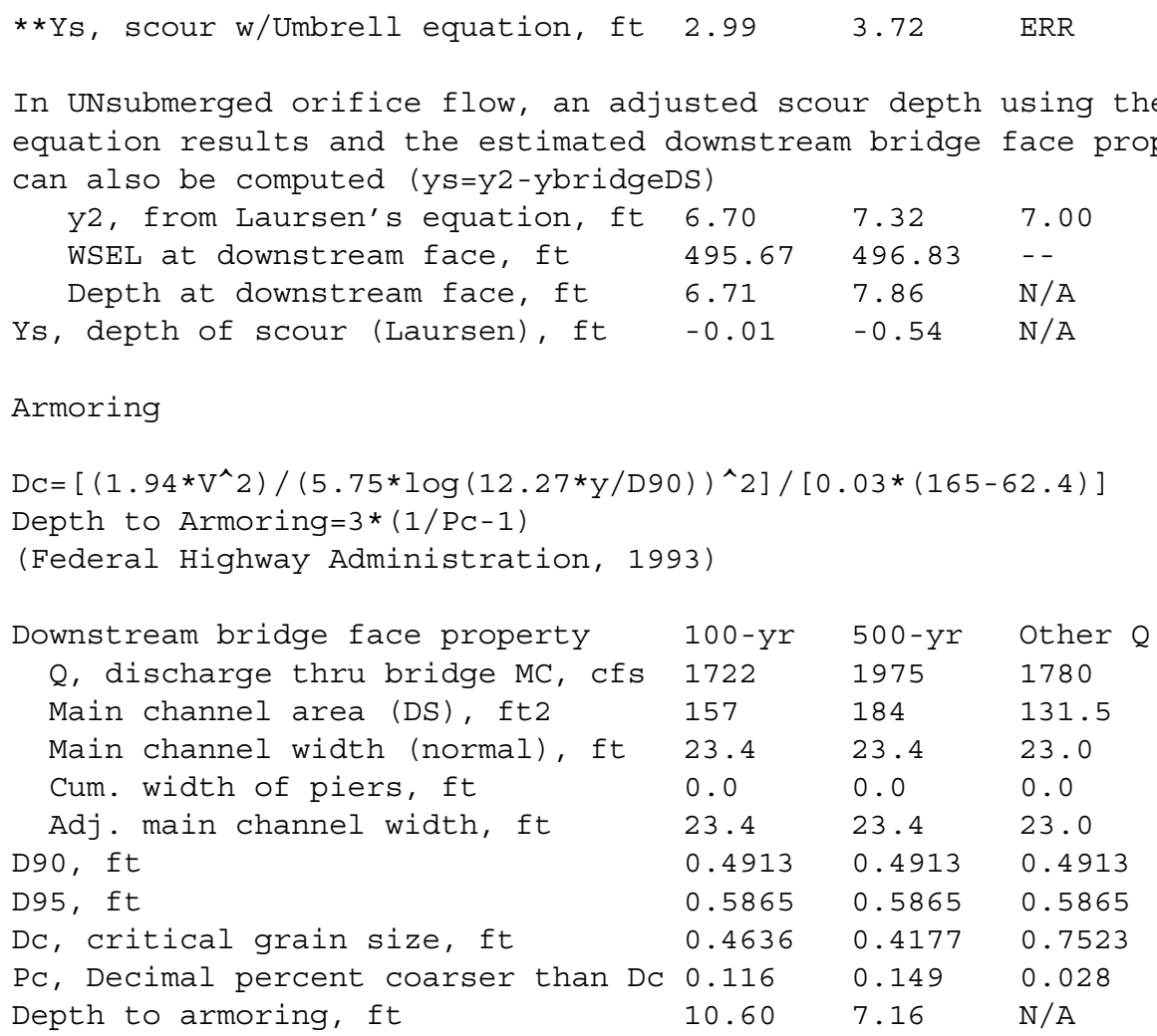

Abutment Scour

Froehlich's Abutment Scour

$\mathrm{Ys} / \mathrm{Y} 1=2.27 * \mathrm{~K} 1 * \mathrm{~K} 2 *\left(\mathrm{a}^{\prime} / \mathrm{Y} 1\right)^{\wedge} 0.43 * \mathrm{Fr} 1 \wedge 0.61+1$

(Richardson and others, 1995, p. 48, eq. 28)

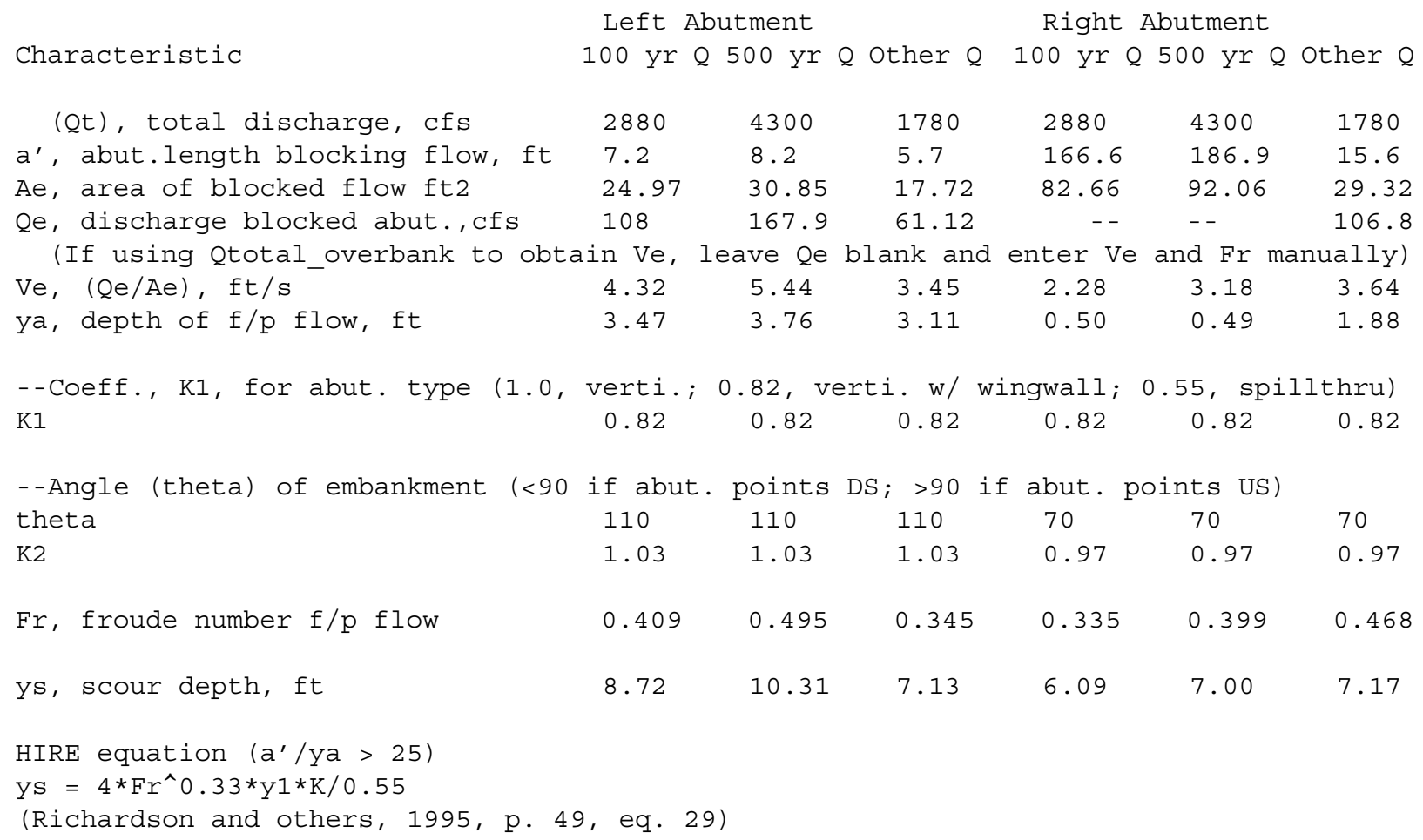




\begin{tabular}{|c|c|c|c|c|c|c|}
\hline$a^{\prime}$ (abut length blocked, ft) & 7.2 & 8.2 & 5.7 & 166.6 & 186.9 & 15.6 \\
\hline y1 (depth $\mathrm{f} / \mathrm{p}$ flow, $\mathrm{ft}$ ) & 3.47 & 3.76 & 3.11 & 0.44 & 0.49 & 1.88 \\
\hline$a^{\prime} / y^{\prime}$ & 2.08 & 2.18 & 1.83 & 335.78 & 379.44 & 8.30 \\
\hline Skew correction (p. 49, fig. 16) & 1.04 & 1.04 & 1.04 & 0.93 & 0.93 & 0.93 \\
\hline Froude no. f/p flow & 0.41 & 0.50 & 0.34 & 0.34 & 0.40 & 0.47 \\
\hline Ys w/ corr. factor $\mathrm{K} 1 / 0.55$ : & & & & & & \\
\hline vertical & $\mathrm{ERR}$ & ERR & $\mathrm{ERR}$ & 2.35 & 2.47 & ERR \\
\hline vertical w/ ww's & ERR & ERR & ERR & 1.92 & 2.02 & ERR \\
\hline spill-through & ERR & ERR & $\mathrm{ERR}$ & 1.29 & 1.36 & ERR \\
\hline Abutment riprap sizing & & & & & & \\
\hline Isbash Relationship & & & & & & \\
\hline $\begin{array}{l}\mathrm{D} 50=\mathrm{Y}^{*} \mathrm{~K} * \mathrm{Fr} r^{\wedge} 2 /(\mathrm{Ss}-1) \text { and } \mathrm{D} 50=\mathrm{Y}^{*} \mathrm{~K} * \\
\text { (Richardson and others, 1995, p11 }\end{array}$ & $\begin{array}{l}\wedge \\
\text { eq. } \\
\text { eq }\end{array}$ & $\begin{array}{l}(\mathrm{Ss}-1) \\
32)\end{array}$ & & & & \\
\hline Characteristic & Q100 & Q500 & Other Q & Q100 & Q500 & Other Q \\
\hline Fr, Froude Number & 0.75 & 0.67 & 1 & 0.75 & 0.67 & 1 \\
\hline$y$, depth of flow in bridge, ft & 6.71 & 7.86 & 5.72 & 6.71 & 7.86 & 5.72 \\
\hline Median stone Diameter for riprap & : left & utment & & right & abutment, & ft \\
\hline Fr<=0.8 (vertical abut.) & 2.33 & 2.18 & ERR & 2.33 & 2.18 & ERR \\
\hline Fr>0.8 (vertical abut.) & ERR & ERR & 2.39 & ERR & ERR & 2.39 \\
\hline
\end{tabular}

